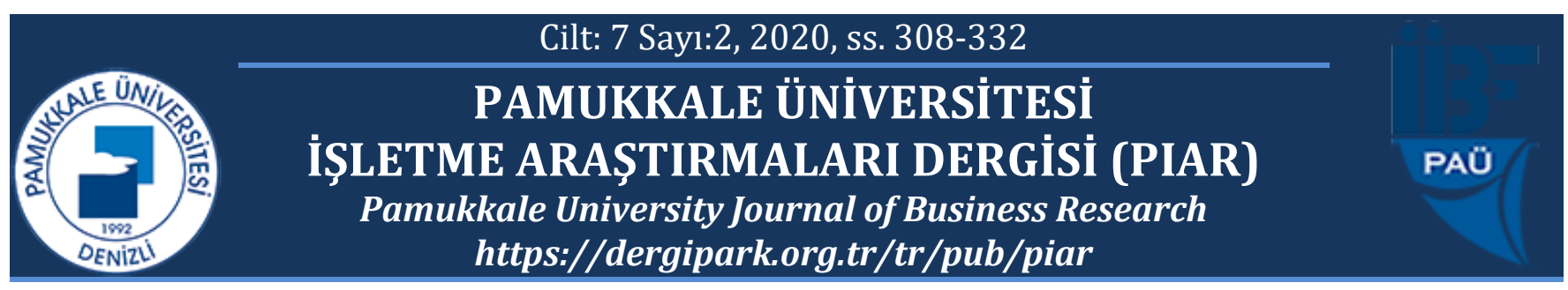

\title{
Liderlik Yaklaşımları ve Spor Yönetiminde Liderlik
}

\section{Leadership Approaches and Leadership in Sports Management}

\section{Özlem IŞIK İNAN ${ }^{*}$}

\section{Celaleddin SERINKAN²}

\footnotetext{
${ }^{1}$ Pamukkale Üniversitesi, SBE, Doktora Öğrencisi, ozlemisikinan@gmail.com, https://orcid.org/0000-0001-8431-0070

${ }^{2}$ Pamukkale Üniversitesi, İ̈BF, İşletme Bölümü, cserinkan@pau.edu.tr, https://orcid.org/0000-0001-8056-2596

* Yazışılan Yazar/Corresponding author
}

Makale Geliş/Received: 10.11.2020

\section{Öz}

Liderlik genellikle en karmaşık sosyal alanlardan biri olarak görülür. Geçtiğimiz yarım yüzyıl boyunca çalışılan liderlik yaklaşımları, liderliğin ne olduğunu açıklamaya çalışmaktadır. Alan yazında üç temel yaklaşım bulunduğu öne sürülebilir: Özellikler yaklaşımı, Davranışsal yaklaşımlar ve Durumsal yaklaşımlardır. Bu yaklaşımlar geleneksel liderlik yaklaşımları olarak ele alınmaktadır. Bunlara ek olarak son dönemde önem kazanmış modern yaklaşımlar da bulunmaktadır. Çalışmamızın amacı liderlik ve liderlik yaklaşımlarına yönelik alan yazın araştırması yaparak, yöneticilik ve liderlik arasındaki farkları ortaya koymaktır. Ayrıca liderlikte modern liderlik yaklaşımlarına dikkat çekerek spor alanında yapılan liderlik çalışmaların literatür taraması şeklinde inceleyerek spor örgütleri için liderlik tarzları ve önemini vurgulamaktır. Tüm hizmet sektörlerinde olduğu gibi spor örgütlerinin başarısı da örgütteki çalışanların ve çalışanlara yön gösteren liderlerin başarısı ile sağlanmaktadır.

Anahtar kelimeler: Liderlik, Liderlik Yaklaşımları, Modern Liderlik Yaklaşımları, Spor Yönetiminde Liderlik

JEL kodları: L2, L83, M13
Makale Kabul/Accepted: 07.12.2020

\begin{abstract}
Leadership is often seen as one of the most complex social areas. The leadership approaches that have been studied for the past half century try to explain what leadership is. It can be suggested that there are three basic approaches in the literature: Trait approach, Behavioral approaches and Contingency approaches. These approaches are considered as traditional leadership approaches. In addition, there are contemporary approaches that have gained importance recently. The aim of our study is to conduct literature research on leadership and leadership approaches by revealing the differences between management and leadership. In addition, attention was drawn to the current leadership approaches in leadership and the leadership studies in the field of sports were examined, the leadership styles and importance in sports organizations were emphasized. As in all service sectors, the success of sports organizations is ensured by the success of the employees in the organization and the leaders who guide the employees.
\end{abstract}

Keywords: Leadership, Leadership Approaches, Modern Leadership Approaches, Leadership in Sports Management

JEL codes: L2, L83, M13 


\section{GİRIŞ̧}

Genel olarak insanlar grup halinde yaşayan sosyal varlıklar olmaları ve belirli amaçlara ulaşmak amacı içinde olmaları nedeniyle gruplar oluştururlar. Dolayısıyla bu gruplarını yönetecek ve grupları hedeflerine ulaştıracak liderlere ihtiyaç duyarlar (Eren, 2014:435). Özellikle küreselleşen ve her an değişim yaşanan günümüz yönetim anlayışında lidere olan ihtiyaç çok daha fazladır.

Yetim (1996) liderliği belirli amaçları şevk ve heyecanla gerçekleştirebilmek için başkalarını ikna edebilme yeteneği olarak tanımlamış ve yöneten ile yönetilen arasındaki bir ilişkiyi kapsadığını vurgulamıştır. Ayrıca liderliği başarılı bir yöneticinin sahip olması gereken önemli bir fonksiyon olarak nitelendirmiştir. Koçel (2005) ise liderlik yerine önderlik kelimesini kullanmış ve belirli şartlar altında örgütsel veya kişisel amaçları gerçekleştirebilmek adına bir kimsenin başkalarının faaliyetlerini etkilemesi ve yönlendirmesi süreci olarak tanımlamaktadır. Liderlik sürecinde kişiler arası etkileşimin önemine vurgu yapmıştır. Liderlik yazınına önemli katkıları bulunan Bass (1990) liderliği; grup üzerine odaklanma süreci, kişisel bir özellik, insanlar arasında uyumu gerçekleştirebilen bir ikna sanatı, başkalarını etkileme çabası, güç ilişkisi, amaca ulaştıran bir araç, bir yapının başlangıcı gibi birbirinden farklı şekillerde açılamaktadır.

Lider kelime anlamı olarak, önderlik yapan, yol gösteren, takipçilerinin istek ve ihtiyaçlarını önceden sezen, yaratıcı kimse olarak belirtilmekte, liderlik ise içinde bulunulan örgütün amaçlarını gerçekleştirebilmek için çalışanları motive ve koordine etme sanatı olarak ifade edilmektedir (Tunçer, 2012: 291). Kılınç (2019) ise liderliği, örgütün ihtiyaç duyduğu ve duyacağı konularda örgüte yön vermek, işgörenlerin güdülenmesini sağlayıp onların verimli ve ahenkli çalışmalarını tesis etmek, örgütsel sorunları kalıcı bir şekilde ortadan kaldırmak ve örgütsel hedeflere ulaşmayı kolaylaştırmak şeklinde tanımlamıştır.

Alan yazındaki liderlik tanımları dikkate alınarak sentez bir tanım yapılacak olursa, insanları belirli bir grup altında belirli amaçlar için toplayarak bu amaçları gerçekleştirebilmek adına grup üyelerini etkileyerek harekete geçirme bilgi, beceri ve yeteneği olarak açıklanabilir. (Eren, 2014:435). Kişileri harekete geçirme süreci için en önemli nokta liderlik becerisine sahip olan kişinin karşısındakileri etkileyebilme yeteneğidir. Liderlik aynı zamanda bir değişim çağrısına öncülük etme eylemidir (Karakaplan Özer, 2019: 43). Dünya çapında yaşanan küresel değişimler işletmeleri daha yenilikçi ve değişime açı hale getirmektedir. Sistem olarak değişim bu değişim sürecine uyum örgütlerdeki liderlerin başarılarına ve örgütünü değişim yönünde etkileyebilme gücüne bağlıdır (Yeşil, 2013: 77).

Tarihin her döneminde liderler ortaya çıkmıştır ve gelecekte de liderlerin yönetim anlayışı içerisinde vazgeçilmeyen bir unsur olacağı bir gerçektir (Tunçer, 2012: 292; Eren, 2014:435). Günümüz modern toplumlarında, insanlar örgütlerde eğitim görür, çalışır, tedavi olur ve hatta boş zamanlarını örgütlerde değerlendirirler, spor yaparlar, eğlenirler (Yetim, 1996: 85). $\mathrm{Bu}$ anlamda bakıldığında da liderlik yaşamımızın her alanında, örneğin çocuk oyunlarında, eğitim hayatında sınıflarda, politik hayatta ya da sivil toplum veya ticari tüm örgütlerde karşımıza çıkmaktadır. Rekabetin yoğun olarak hissedildiği, çalışanların mutluluk, moral ve tatmin düzeylerinin örgütün verimlilik ve başarısını yoğun şekilde etkilediği, bilgi, beceri ve yeteneğin en değerli kaynaklar olarak ele alındığı günümüz toplumunda, etkili liderlik 
büyük bir gereksinimdir. Ayrıca liderlerin işlevleri de geçmişe oranla örgütlerin yönetiminde çok etkili bir unsur olarak yerini almaktadır (Karakaplan Özer, 2019: 44).

Modern yönetim anlayışı kapsamında örgütlerin yönetimleri incelendiğinde yönetici yerine lider kavramı daha yaygın şekilde kullanılmaktadır. Günümüz örgütleri değişen koşullara ayak uydurabilmesi ve küresel rekabet koşullarında başarı elde edebilmesi için teknolojik donanıma sahip olması yanında liderlik vasıflarına sahip yöneticilere ihtiyaç duymaktadırlar (Serinkan, 2010:150). Örgüt kaynakları her ne kadar değişime ayak uyduracak nitelikte olur ise olsun bu kaynakları organize edecek ve çalışanların sinerji etkisi yaratacak şekilde çalışmalarını sağlayacak bir lidere ihtiyaç duyulduğu birçok çalışma ile kanıtlanmıştır (Tunçer, 2012:290).

Wanasika (2006) küreselleşmenin örgütleri farklı düzeylerde etkilediğini belirtmektedir. Bu etkileşim liderlik yaklaşımlarını da önemli ölçüde etkilemekte ve liderlik anlayışlarında değişimi gerektirmektedir. Liderlerin sermayenin ve emeğin serbest akışı, değişen teknolojiler ve kültürel dinamikler gibi ortaya çıkan küresel zorluklarla etkili bir şekilde mücadelesi için daha çeşitli niteliklere, bilgi ve donanıma sahip olmaları gerekliliği birçok araştırmada öne sürülmektedir.

Alan yazındaki çalışmalar incelendiğinde günümüz iş dünyası için geçmişten günümüze kadar ortaya atılmış liderlik yaklaşımlarını inceleyerek ve harmanlayarak yeni Dünya anlayışına uygun liderlik yaklaşımları oluşturulmaktadır. Bu çalışmanın amacı liderlik konusunda var olan kuramsal bilgileri ortaya koymak, geleneksel liderlik yaklaşımlarını ve modern liderlik yaklaşımlarını özetleyerek gelişen dünya dinamikleri çerçevesinde özellikle spor alalında çalışan liderlere ve araştırmacılara ışık tutmaktır.

\section{LIDER VE YÖNETICİ FARKI VE LIDERLİK ÖZELLİKLERİ}

Yönetici ve lider alan yazında zaman zaman eş anlamlı olarak kullanılmaktadır (Paksoy, 2010:24). Ancak benzerlikleri yanında her iki kavram çok farklı özelliklere sahiptir. Yetim (1996)'e göre yönetici bir örgütün hedeflerini gerçekleştirirken, örgütün en etkili ve en yeterli şekilde işlemesini sağlayabilen kişiler olarak tanımlanmıştır. Bu tanımdan da yola çıkarak yönetici, mevzuat ve sistem odaklı, kendisine bildirilen işi başarılı şekilde yapmaya çalışan, mevcut düzeni kabul eden, astlarına karşı otoriter ve sert olan, kontrol odaklı ve hata arayan, hataları bulduğunda cezalandıran kişilerdir. Liderlik tanımlarından da yola çıkarsak lider ise, yenilikçi ve geliştirici, insan odaklı çalışan astlarına güvenen ve onlar ile olumlu iletişimde bulunan, strateji ve hedefleri kendi belirleyebilen, risk ve sorumluluk alabilen, hedeflere ulaşmada astlarını destekleyen ve ödüllendiren kişidir (Tunçer, 2012: 292-293). Liderin en önemli özelliği takipçilerini bir hedef etrafında zorunlu olarak değil etkileyerek toplamasıdır (Serinkan, 2010: 151). Lider etkileyici gücünü sosyal iletişim yolları ile elde etmekte yönetici ise resmi yollarla elde etmektedir (Yeşil 2013: 79).

Yönetici genel olarak gelişimi yani önceden belirlenmiş sınırlar çerçevesinde en iyi ve mükemmeli yakalama çabası içerisindedir. Lider ise değişimi yani mevcut sistemin dışında farklı yollar seçerek sınırların dışında yeni bir dünya kurma amacı içerisindedir. Lider takipçilerini bir amaç ve vizyon etrafında toplar ve onları motive eder. (Tunçer, 2012: 293). Kısacası yönetici, var olan durumu sürdürme üzerine yoğunlaşırken, lider ise yaratıcı süreçleri harekete geçirmeye çalışır (Köseoğlu, 2019: 20). 
Yöneticilerin örgüt amaçlarına yönelik tutumları daha şahsi, çekinden ve otoriteden etkilenmektedir. Liderlerin ise amaçlarına yönelik tutumları daha dinamik bir yapıya sahiptirler. Otoriteden gelen yeni fikirleri uygulamak yerine yeni fikirler üretirler. Ayrıca liderler ikna yetenekleri sayesinde diğer kişilerin görüş ve düşüncelerini değiştirebilirler (Yeşil, 2013: 79).

Güney (2001) lider ve yönetici arasındaki farklarını ayrı ayrı özelliklerini yazarak bir tablo olarak ifade etmiştir.

Tablo 1: Lider ve Yönetici Arasındaki Farklar

\begin{tabular}{|l|l|}
\hline \multicolumn{1}{|c|}{ Yönetici Özellikleri } & \multicolumn{1}{|c|}{ Lider Özellikleri } \\
\hline Yöneticidir. & Yenilikçidir. \\
\hline Düzeni sürdürür. & Farklılık yaratır. \\
\hline Koruyucudur. & Geliştiricidir. \\
\hline Sistem ve yapı merkezlidir. & Birey merkezlidir. \\
\hline Kontrol eğilimlidir. & Güveni özendiricidir. \\
\hline Kısa dönemli bakış açısına sahiptir. & Uzun dönemli bakış açısına sahiptir \\
\hline Nasıl ve ne zaman sorularına önem verir. & Ne ve niçin sorularına önem verir. \\
\hline Alt yönetsel kademelere bakışa sahiptir. & Çevreye bakış. \\
\hline Mevcut durumu kabul etme eğilimi. & Mevcut durumu sorgulama eğilimi. \\
\hline Yerleşik normlara uygun işgören ister. & Kendisi iş görenlerini seçer. \\
\hline İşi doğru yapan kişidir. & Doğru işi yapan kişidir. \\
\hline Yapıyı Korumayla İlgilenir & Değişimle ilgilenir \\
\hline Yasal gücünü kullanır, ödül ve cezaya dayalı gücü vardır. & Yönlendiricidir, kişisel erkini kullanır. \\
\hline Düzeni sürdürür & Farklılık yaratır. \\
\hline Gücünü Statüden alır & Gücünü etkileşimden alır \\
\hline
\end{tabular}

Kaynak: (Güney, 2001:287; Köseoğlu, 2019:22).

Alan yazına bakıldığında örgüte amaçları doğrultusunda yön veren, örgüt üyelerini etkileyen ve yeni bir vizyon oluşturan kişiler, hem yöneticilik hem de liderlik becerileri bakımından incelenmiştir. Birçok çalışmada örgütlerdeki yöneticilerin liderlik özelliklerinin örgütsel etkinlik ve başarıda daha önemli rol oynadığı ortaya koyulmuştur (Yeşil, 2016: 159).

Lider ile yönetici arasındaki pek çok farklar bulunmaktadır. Ancak bunların arasındaki en önemli farklılık; liderlerin değişimden yana olduğu ve izleyicilerini istekli şekilde bir yönden başka tarafa sevk ve idare edebilmesi yani etkileme gücü iken yönetici ise mevcut sistemin devamından yana davranış sergilemesidir.

Aslında lider ile yöneticinin farklı kavramlar olmasının yanısıra bazı çalışmalarda lideryöneticilerden bahsedilmektedir. Bilindiği üzere lider olmak için resmi yetkilerle donatılmak şart değildir. Ancak bu kavram ile yani lider-yönetici kavramında, liderlik vasfına sahip olan kişilerin aynı zamanda yönetici olarak yetki verilmesini içermektedir. Diğer bir anlatımla lider-yöneticiler, işlerin başına getirilip yasal gücün kullanılma yetkisine sahip olmaları gerekmektedir. Bu durumda lider-yöneticiler, hem astlarını istekli ve şevkli bir şekilde sevk ve idare edebilecek, hem de resmi yetkinin verilmesiyle gerekli kaynakların kullanımında daha rahat olacaklardır. Diğer taraftan liderlik vasfına sahip olmayan yöneticiler ise astlarını-izleyicilerini istekli bir şekilde sevketmek yerine yasal gücüne dayanarak emir verme, korkutma ve tehdit ile iş yaptırmaya çalışacaktır. 
Aşağıda liderlik yaklaşımlarından olan geleneksel, davranışsal ve durumsal liderlik teorileri açıklanmaktadır.

\section{LIDERLIKK YAKLAŞIMLARI}

Örgütleri başarıya ulaştıracak liderlik modelini geliştirmeye yönelik araştırmalar günümüzde de halen sürdürülmeye devam etmektedir. Liderlik sürecinde liderin kişisel özelliklerinin önemli olduğu, fakat sadece bu boyutun yeterli olmadığı ve değişen koşulların ve durumların liderlik sürecini etkilemesi yanında liderlik tarzını belirlediği bilinmektedir. Jiang (2014) yapmış olduğu alan yazın taraması sonucunda tarihsel süreç içerisinde ortaya çıkmış liderlik tarzları ve özelliklerini hakkında tablo oluşturmuştur;

Tablo 2: Liderlik Tarz ve Özelliklerinin Tarihsel Gelişimi

\begin{tabular}{|c|c|c|c|c|}
\hline & Yaklaşım & Tarihler & Ana Düşünce & Liderlik Tarzı \\
\hline \multirow{3}{*}{$\begin{array}{l}\text { Geleneksel } \\
\text { Liderlik } \\
\text { Yaklaşımları }\end{array}$} & $\begin{array}{c}\text { Kişisel Özellikler } \\
\text { Yaklaşımı }\end{array}$ & 1930-1940 & $\begin{array}{l}\text { Liderler Üstün Özellikler } \\
\text { İle Doğarlar }\end{array}$ & Tanımlı Değil \\
\hline & $\begin{array}{l}\text { Davranışsal } \\
\text { Yaklaşımlar }\end{array}$ & 1940-1960 & $\begin{array}{l}\text { Liderlik } \quad \text { Özellikleri } \\
\text { Sonradan Öğrenilebilir. }\end{array}$ & $\begin{array}{c}\text { Özgürlükçü } \\
\text { Demokratik } \\
\text { Otokratik } \\
\text { Bürokratik }\end{array}$ \\
\hline & $\begin{array}{l}\text { Durumsal } \\
\text { Yaklaşımlar }\end{array}$ & $\begin{array}{l}\text { 1960'lar ve } \\
\text { sonrası }\end{array}$ & $\begin{array}{l}\text { Farklı Durumlarda Farklı } \\
\text { Liderlik } \quad \text { Tarzlarının } \\
\text { Bulunması }\end{array}$ & $\begin{array}{c}\text { Direktif } \\
\text { Destekleyici } \\
\text { Katılımcı } \\
\text { Başarı odaklı }\end{array}$ \\
\hline \multirow{3}{*}{$\begin{array}{c}\text { Modern } \\
\text { Liderlik } \\
\text { Yaklaşımları }\end{array}$} & $\begin{array}{c}\text { Vizyoner veya } \\
\text { Karizmatik Liderlik } \\
\text { Yaklaşımları }\end{array}$ & 1980-1990 & $\begin{array}{l}\text { Liderlik Tarzları Sürecin } \\
\text { Durumuna ve İlişkilere } \\
\text { Göre Tanımlanmaktadır. }\end{array}$ & $\begin{array}{c}\text { İşlemsel } \\
\text { Dönüşümcü } \\
\text { Özgürlükçü }\end{array}$ \\
\hline & $\begin{array}{l}\text { Duygusal Zeka } \\
\text { yaklaşımı }\end{array}$ & $\begin{array}{l}\text { 1990'lar ve } \\
\text { sonrası }\end{array}$ & $\begin{array}{l}\text { Liderlerin Duygusal Zekası, } \\
\text { Astların Performansını } \\
\text { Daha Çok Etkilemektedir. }\end{array}$ & $\begin{array}{c}\text { Vizyoner } \\
\text { Koçluk } \\
\text { Yakınlık } \\
\text { Demokratik }\end{array}$ \\
\hline & $\begin{array}{c}\text { Tam Kapsamlı } \\
\text { Liderlik Yaklaşımı }\end{array}$ & $\begin{array}{l}2000 \text { ve } \\
\text { sonras1 }\end{array}$ & $\begin{array}{l}\text { Liderin Kişisel Özellikleri, } \\
\text { Nitelikleri Ve Becerileri } \\
\text { Tam Kapsamlı Olarak } \\
\text { Etkilemektedir. }\end{array}$ & $\begin{array}{c}\text { Merak Uyandıran } \\
\text { Kapsamlı } \\
\text { Hedef Odaklı }\end{array}$ \\
\hline
\end{tabular}

Kaynak: (Jiang, 2014: 52).

Liderliğe dair yaklaşımlar farklı yönetim bilimciler tarafından farklı başlıklar altında kategorize edilmektedir. Genel olarak incelediğimizde ise liderlik yaklaşımları "liderlikte geleneksel yaklaşımlar" ve "liderlikte güncel yaklaşımlar" olmak üzere iki başlık altında ele alınmaktadır (Karakaplan Özer, 2019: 43).

\subsection{Geleneksel Liderlik Yaklaşımları}

1900-1970 yılları arasında liderlik üzerine pek çok çalışma yapılmış ve bu yıllar arasında yapılmış olan çalışmalar geleneksel liderlik yaklaşımları olarak sınıflandırılmaktadır. Yirminci yüzyıl içinde yoğunlaşan liderliği anlama çabaları nedeni ile çok farklı disiplinde birçok çalışma yapılmış, bu çalışmalar farklı bakış açılarının ortaya çıkmasına neden olmuştur (Ekşili, 2019: 26). Genel olarak bu farklı fikirler ve bakış açıları farklı grupta yer almaktadır. Geleneksel yaklaşımlar; özellikler yaklaşımı, davranışsal yaklaşımlar ve durumsallık yaklaşımı olarak üç alt grupta toplanmaktadır. Ayrıca son dönemde yapılan çalışmaların sonucunda modern liderlik yaklaşımları altında dönüşümcü liderlik, etkileşimci 
liderlik, stratejik liderlik, karizmatik liderlik, vizyoner liderlik, etik liderlik gibi farklı liderlik yaklaşımları yer almaktadır. Çalışmamızda söz konusu yaklaşımlar kısaca açıklanmaya çalışılacaktır.

\subsection{1. Özellikler Yaklaşımı}

Liderlik konusundaki ilk geliştirilen yaklaşımlar bu grup yaklaşımlar altında toplanmaktadır (Koçer, 2005:587). Erken dönem liderlik araştırmaları (1900'lü yıllar) liderlerin sahip olduğu kişilik özellikleri üzerinde yoğunlaşmıştır. Etkili liderlerin doğuştan sahip oldukları özellikler nedeniyle lider oldukları varsayımına dayanmaktadır. Bu nedenle alan yazında özellikler teorisi, alan yazında büyük adam teorisi (the great man theory) olarak da isimlendirilmektedir. Bu çalışmalara yönelen araştırmacıların yanıtlarını öğrenmek istedikleri araştırma soruları (Aksel, 2010:34);

- $\quad$ Liderlerin sahip olduğu kişilik özellikleri nelerdir?

- $\quad$ Liderlik özellikleri doğuştan gelmekte midir?

- $\quad$ Liderlik özellikleri zaman içerisinde deneyimle mi kazanılır?

$\mathrm{Bu}$ yaklaşım çerçevesinde bir kişinin lider olarak belirlenmesi ve bu grubu yöneten kişi olarak kabul edilmesinin sebebi lider olan kişinin sahip olduğu özelliklerinden kaynaklandığı konusunda görüş birliğine varılmıştır. Kısacası lider sahip olduğu bu özelliklerle diğer grup üyelerinden ayrılmaktadır. (Güney,2001:288; Koçer, 2005: 587). Bu yaklaşım başarılı ve başarısız liderlerin karakter özelliklerinin incelenmesine dayanmaktadır (Aksel, 2010: 34) Alan yazın incelendiğinde liderlerin farklı özelliklerinden bahsedilmekte ve ortak bir fikir birliği bulunmamaktadır. Alan yazındaki pek çok çalışmada ortaya konulan liderlik özelliklerini bir araya getirilerek gruplandırma yaparsak; 
Tablo 3: Özellikler Yaklaşımı Lider Özellikleri

\begin{tabular}{|c|c|}
\hline Genel Özellik Grubu & Alt Özellikleri \\
\hline Kişilik Özellikleri & $\begin{array}{ll}\text { - } & \text { Yaratıcılık } \\
\text { - } & \text { Açıgözlülük } \\
\text { - } & \text { Dürüstlük } \\
\text { - } & \text { Etiksel davranış } \\
\text { - } & \text { Kendine germe güven (öz güven) } \\
\text { - } & \text { Dişa dönüklük }\end{array}$ \\
\hline Fiziksel Özellikler & $\begin{array}{ll}\text { - } & \text { Enerjik olma } \\
\text { - } & \text { Fiziki görünüm } \\
\text { - } & \text { Boy } \\
\text { - } & \text { Kilo } \\
\text { - } & \text { Yaş } \\
\text { - } & \text { Cinsiyet } \\
\end{array}$ \\
\hline Yeteneksel Özellikler & $\begin{array}{ll}\text { - } & \text { Zeki olma } \\
\text { - } & \text { Yargilama } \\
\text { - } & \text { Bilgi sahibi olma } \\
\text { - } & \text { Akıci konuşma } \\
\text { - Kesinlik }\end{array}$ \\
\hline İşe İlişkin Özellikler & $\begin{array}{ll}\text { - } & \text { Başarı güdüsü } \\
\text { - Ileride olma arzusu } \\
\text { - } & \text { Sorumluluk alabilme } \\
\text { - } & \text { Göreve dönüklük } \\
\text { - } & \text { Amaçlara ulaşmada sorumluluk alabilme } \\
\end{array}$ \\
\hline Sosyal Özellikler & $\begin{array}{ll} & \text { İşbirliği yeteneği } \\
\text { - } & \text { Prestij } \\
\text { - } & \text { Popüler ve sosyal olma } \\
\text { - } & \text { Kişiler arası iletişim } \\
\text { - } & \text { Sosyal katıllım } \\
\text { - } & \text { Kültür düzeyi } \\
\text { - } & \text { Hiplomasi } \\
\end{array}$ \\
\hline
\end{tabular}

Kaynak: (Güney, 2001:288-289; Yeşil, 2013: 80-81 )

Özellikler yaklaşımına yapılan eleştirilerden birincisi başarılı sayılan liderlerin özellikleri tanımlanırken tutarlı bir sonuca varılamamış ve yüzden fazla özellik tanımlanmıştır. Liderlerin sektörlerine veya pozisyonlarına bağlı olarak farklı özelliklere sahip olduğu tespit edilmiştir. Eleştirilerden ikincisi de tanımlanan bu özelliklerden fiziksel özelliklere daha çok önem verilmesidir. Yani liderin boyu, kilosu, diş görünümü gibi özelliklerin başarılı liderlerin tanımlanmasında etkili görülmesi tüm liderler için doğru sayılamamaktadır (Aksel, 2010: 35). Örneğin etkili liderlerin uzun boylu olduğu iddiası için M. Kemal Atatürk, Napolyon, Mussolini, Hitler gibi dünyada büyük etkiler yaratmış liderlerin boylarının kısa olması bu iddianın aksini düşündürmektedir. Ayrıca ülkemiz için önemli bir yeri olan ve 1980'li yıllara damgasını vuran bir lider olan Turgut Özal da kısa boyludur.

Sonuç olarak özellikler yaklaşımını öne süren kuramcıların kendi çalışmalarında da bir fikir birliğine varamaması ve çalışmalardan pek verim alınamaması eleştirilere neden olmuştur. Çalışma sonuçları, grup yöneticilerinin kişisel özellikleri açısından lider olarak seçilmeleri ve başarıları konusunda büyük bir etkiye sahip olmadığı ve hatta sığ kaldığ belirtilmiştir. Ayrıca örgütlerin kültürleri veya toplumların özellikleri nedeniyle her liderin her örgütte veya her toplumda lider olarak görülmeyebileceği görüşü ortaya atılmıştır. Özellikler 
yaklaşımına yapılan bu eleştiriler ve liderlik konusunda bu yaklaşımın yetersiz kalması nedeni ile araştırmacılar liderin takipçilerinin özelliklerini ve liderin davranışlarını araştırmaya yönelmişlerdir (Koçel, 2005: 589; Tunçer, 2012: 301;Yeşil 2013: 81; Ekşili, 2019: 2627).

\subsubsection{Davranışsal Yaklaşımlar}

Liderlerin özellikleri üzerine yapılan araştırmalar sonucunda liderlerin genel olarak aynı özellikleri göstermediğinin saptanmasıyla, 1940-1960 yıllarında yapılan çalışmalarda dikkatler liderlerin davranışlarına yönelmiştir (Küçüközkan, 2015: 88). Liderlikteki davranışsal yaklaşım, o dönemde özellikler yaklaşımının çok verimli ve etkin olmadığının anlaşılması nedeniyle geliştirilen yeni bir yaklaşımdır.

Davranışçı yaklaşıma göre lider belirli davranış özellikleri göstermektedir. Bunlar; liderin grup üyeleri ile olan iletişimi, örgüt amaçlarını belirleme şekli, örgüt içinde karar alma, planlama ve denetim şekli, yetki devri özelliği ve örgüt üyelerini motive etme şekli gibi davranışlardır. Yaklaşıma göre tüm bu sergilediği davranışlar da liderin başarı ve etkinliğini belirlemektedir (Tunçer, 2012: 299-300). Liderlik, liderin özelliklerinden çok yapmış olduğu faaliyet ve davranışların grup tarafında sonuçlarının kabul görmesi ve beğenilmesi ile ortaya çıkmaktadır (Aksel, 2010: 36). Dolayısıyla bu yaklaşım liderin davranışları yanında ikinci bir etken olarak liderin takipçilerini de ele almaktadır (Koçel, 2005: 589). Ayrıca liderlik özelliğinin sadece doğuştan gelmediği ve geliştirilebildiği bu yaklaşımın önemli bir varsayımıdır.

Davranışsal yaklaşımcı araştırmacıların yanıtları öğrenmek istedikleri araştırma soruları ise (Küçüközkan, 2015: 88);

- Etkin ve etkin olmayan liderlerin davranış özellikleri nelerdir?

- Lider davranışları etkin liderlikle nasıl bütünleştirilebilir?

- Bir lider, etkin bir lider olabilmek için ne yapmalıdır?

Davranışsal liderlik yaklaşımları çerçevesinde liderin davranışlarını ele alan çalışmalar yapılmıştır. Bu çalışmalar ise;

- Ohio State Üniversitesi liderlik Araştırmaları,

- Michigan Üniversitesi liderlik Araştırmaları,

- Blake ve Mouton'un Yönetim Tarzı Matrisi

- McGregor'un X ve Y Yaklaşımlarıdır.

Bu çalışmaların sonucu olarak değişik liderlik tarzları belirlenmiş ve bunların etkinlikleri araştırılmıştır.

\subsubsection{Ohio State Üniversitesi Liderlik Araştırmaları}

1940 - 1950 yılları arasında Ohio State Üniversitesinde yapılan liderlik araştırmaları davranışsal liderlik yaklaşımı kapsamında üzerinde durulan en kapsamlı çalışmalardan birisidir. Bu çalışmalar ile " Liderlik Davranışlarını Belirleme Anketi” oluşturulmuştur (Tunçer, 2012:302). Yapılan kapsamlı çalışmalar sonucunda lider davranışları açısından 
birbirini tamamlayan ancak birbirinden ayrılan iki boyut belirlenmiştir (Güney, 2001: 290; Koçel, 2005: 590-591; Ağlargöz, 2012: 56-57; Tunçer, 2012: 302-303).

Tablo 4: Ohio State Üniversitesi Liderlik Araştırmaları Boyutları

\begin{tabular}{|c|c|}
\hline 1. Anlayış (Kişiyi Dikkate Alma) & 2. Yapıyı Harekete Geçirme (İnisiyatif) \\
\hline $\begin{array}{l}\text { Lider ile takipçileri arasında güven, saygı ve etkili } \\
\text { ilişkileri ifade eden boyuttur. } \\
\text { Liderin takipçilerinin ihtiyaçlarıyla yakından } \\
\text { ilgilenmesini ve bu doğrultuda davranmasını } \\
\text { gerektirmektedir. } \\
\text { Takipçiler liderlerini kendi istek ve ihtiyaçlarının } \\
\text { bir temsilcisi veya sözcüsü olarak görürler. } \\
\text { Lider takipçilerini takdir eder ve gerektiğinde } \\
\text { ödüllendirir. }\end{array}$ & $\begin{array}{l}\text { Liderin takipçilerini harekete geçirmesi için sergilediği } \\
\text { davranışları ele alan boyuttur. } \\
\text { - Lider örgüt amaçlarını belirler. } \\
\text { - Liderin işin zamanında ve doğru yapması için } \\
\text { takipçilerini yönlendirmesini ele almaktadır. } \\
\text { - Lider işi planlar ve koordine eder. } \\
\text { - Lider takipçilerine görevlerin dağıtımını sağlar. } \\
\text { - Liderin iş ile ilgili tüm süreçlere karar vermesi ve } \\
\text { çalışanlarını harekete geçirmesi sürecidir. }\end{array}$ \\
\hline $\begin{array}{l}\text { Sonuçları: } \\
\text { Liderin anlayışa yönelik davranışlarının artması; } \\
\text { - İş tatminini artırır } \\
\text { - Devamsızlığı ve iş gücü devir hızını azaltır. }\end{array}$ & $\begin{array}{l}\text { Sonuçları: } \\
\text {-Yapıyı harekete geçirme davranışı arttıkça, takipçilerin } \\
\text { performansı dolayısı ile liderin işteki başarısı artar. }\end{array}$ \\
\hline
\end{tabular}

Kaynak: (Güney, 2001: 290; Koçel, 2005: 590-591; A ğlargöz, 2012: 56-57; Tunçer, 2012: 302-303)

\subsubsection{Michigan Üniversitesi Liderlik Araştırmaları}

Rensis Likert ve Michagen Üniversitesi araştırmacıları tarafından 1947 yılında yapılan bir dizi çalışmaları kapsamaktadır. Bu çalışmalar takipçilerin tatminine ve verimliliğe katkı sağlayan faktörleri belirlemek amacıyla yapılmıştır. Bu çalışmalar sonucunda da iki ayrı faktör belirlenmiştir (Güney, 2001: 290; Koçel, 2005: 590-591; Ağlargöz, 2012: 56-57; Tunçer, 2012: 302-303).

Tablo 5: Michagan Üniversitesi Liderlik Araştırmaları Boyutları

\begin{tabular}{|c|c|}
\hline 1. İş görene Yönelik Liderlik & 2. İşe Dönük Liderlik \\
\hline 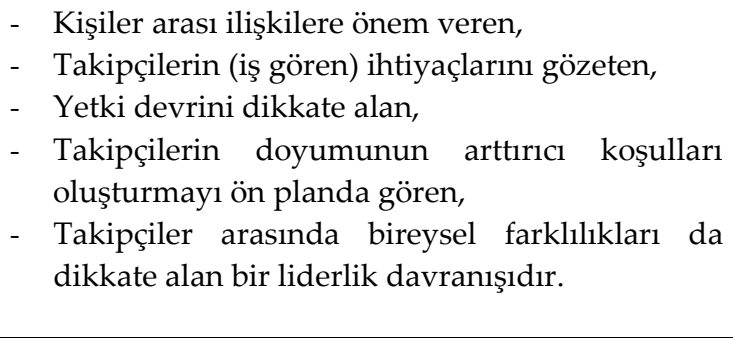 & 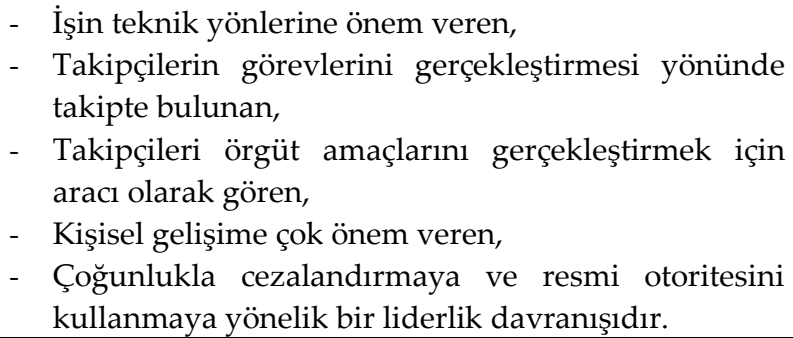 \\
\hline $\begin{array}{l}\text { Sonuçları: } \\
\text { Liderin iş görene yönelik davranışlarının artması; } \\
\text { - Yüksek düzeyde verimlilik ve iş tatmini } \\
\text { sağlamaktadır. } \\
\text { - Yüksek başarı sağlamaktadır. }\end{array}$ & $\begin{array}{l}\text { Sonuçları: } \\
\text { Liderin işe yönelik davranışlarının artması; } \\
\text { - Düşük düzeyde iş gören tatminine neden } \\
\quad \text { olmaktadır. }\end{array}$ \\
\hline
\end{tabular}

Kaynak: (Güney, 2001: 290; Koçel, 2005: 590-591; Ağlargöz, 2012: 56-57; Tunçer, 2012: 302-303).

Honner (1997)'a göre aynı dönemde yapılan çalışmalar olan Michagan Üniversitesi araştırmalarının Ohio State Üniversitesi araştırmasından farkı, liderin her iki davranış biçimini benimseyememesidir. Bu iki davranıştan herhangi birine yönelik davranışta bulunabileceği görüşüdür. Buna karşıt olarak Ohio State Üniversitesi araştırmalarında bir liderin iki davranış türünü de yüksek ya da düşük düzeylerde birlikte sergileyebileceği ileri sürülmektedir (AKT: Cevrioğlu, 2007:9). 


\subsubsection{Blake ve Mouton'un Yönetim Tarzı Matrisi}

Robert Blake ve Jane Mouton 1964 yılında yaptıkları çalışmaları ile yöneticilerin davranışlarının incelendiği Ohio States Üniversitesi ve Michagan Üniversitesi araştırmalarının sonuçlarını bir araya getirerek bir matris oluşturmuşlardır. Bu matrise de "Yönetim Tarzı Matrisi" ismini vermişler (Koçel, 2005: 593). Bu matriste yönetici davranışları “ Üretim Odaklı Liderlik" ve "İnsan Odaklı Liderlik" olarak iki boyutta toplanmaktadır. Matris üzerinde her iki boyutu eksenlere yerleştirerek, boyutları da 9 farklı bölüme ayırmışlar. 1 en düşük 9 ise en yüksek ilgiyi ifade etmektedir. Oluşturulan modele göre her iki boyutun bileşenleri sonucunda 81 farklı liderlik tipi elde edilmiştir. Bunlardan beş tanesi ön plana çıkmaktadır ( Güney, 2001: 291; Kılıç, 2019: 18).

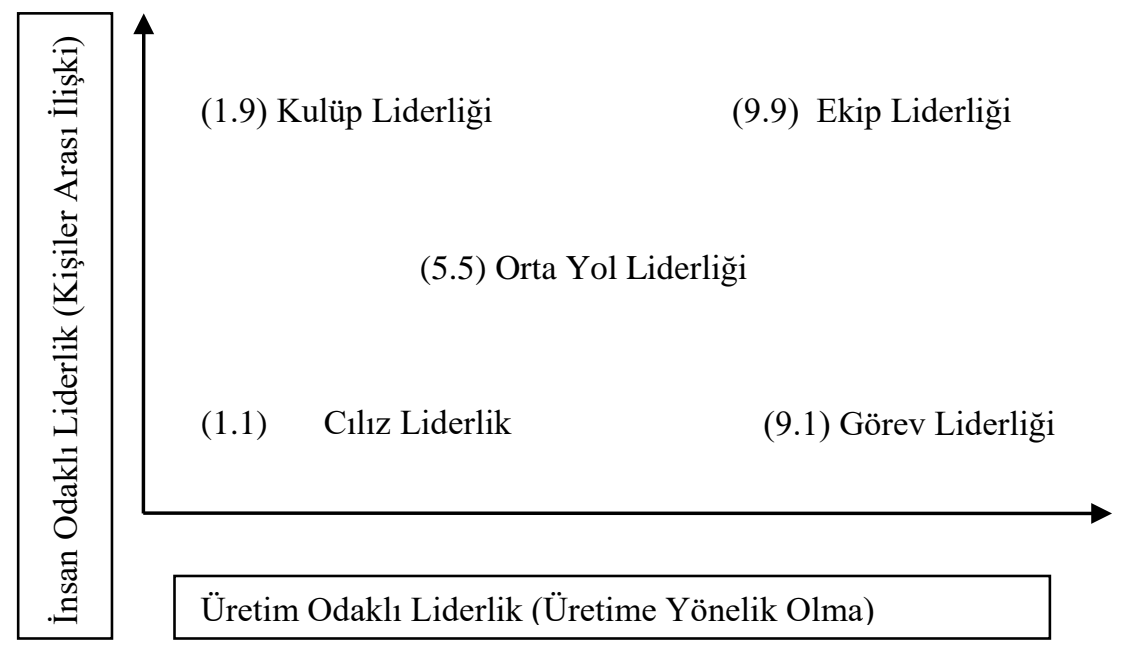

Şekil 1: Blake ve Mounton'un Yönetim Tarzı Matrisi

Kaynak: (Güney,2001: 291)

Şekil 1'de, Blake ve Mounto'nun yönetim matrisindeki öne çıkan beş liderlik tipi gösterilmektedir. Bu liderlik tarzlarının genel özellikleri ise (Güney, 2001: 292; Aksel, 2010: 42-43; Tunçer 2012: 306-307; Küçüközkan, 2015: 93-94);

(1.1) Başarısız Yönetim (Cılız Liderlik): Liderin insan odaklı ve üretim odaklı davranışları minimum düzeydedir. Lider ast ve üstleri ile mesafeli bir ilişki sergilemekte, planlamaya zaman ayırmamakta ve yaratıcılığa ilgisi en az düzeydedir. Bu tarz lider çatışmalardan hoşlanmamaktadır.

(1.9) Kulüp Liderliği: Bu tarz lider insan odaklı davranışları üst düzeyde ancak üretime odaklı davranışları ise en alt düzeydedir. Liderin duyarlı olduğu konu astlarının duygu, düşünce ve memnuniyetleridir. Örgütsel amaçların gerçekleşmesi önemlidir ancak astlarına bu konuda baskıda bulunmaz. Çatışma durumlarında cezadan çok uzlaşma ve astlarıyla konuşma yolunu tercih etmektedir.

(9.1) Görev Liderliği: Bu tarz lider insan odaklı davranışları yok denecek kadar az ancak üretime odaklı davranışları ise en üst düzeydedir. Bu tip lider, planlama yapar, başarıyı kar ve üretim ile ölçer ve astları ile ilişkilerinde otorite-itaat önem taşımaktadır. Çatışmalarını ceza gibi çalışanların aleyhine olacak şekilde çözmeyi tercih eder. Herkesin görevleri kurallar ile sınırlı olması nedeni ile yaratıcılık bu lider davranışında beklenmez. 
(9.9) Ekip Lideri: Bu tarz lider insan odaklı davranışları ve üretim odaklı davranışlarında da üst düzeydedir. Bu tarz lider için örgütte güven ve saygı üst düzeydedir. Çatışmalarda karşılıklı anlaşma ve uzlaşma söz konusudur taraflar soruna ortak çözüm yolları üretmektedir. Lider yaratıcıdır ve yeni yaklaşımlara, değişime istek duyar. Başarı örgütsel performans ve bireysel motivasyon ile gerçekleşeceği bilinci hakimdir. İdeal liderlik davranışı olarak nitelendirilmektedir.

(5.5) Orta Yol Liderlik: Bu tarz lider insan odaklı davranışları ve üretim odaklı davranışlarında da orta düzeydedir. Lider yapılacak iş ve çalışanların moralini dengede tutma çabasındadır. Lider planlama ve görev dağılımı yapar sonrasında işlerin yürümesi için tavsiyelerde bulunur. Hata ve aksaklık durumunda ceza yerine astlarına bir şans daha vermeyi tercih eder. Ancak bu lider tarzında yaratıcılık yoktur ve bu nedenle değişimde istenmemektedir.

\subsubsection{McGregor'un X ve Y Yaklaşımı}

Douglas McGregor tarafından geliştirilen yaklaşım 1930-1950 yılları arasında yani ikinci dünya savaşı, büyük buhran ve soğuk savaş gibi dünya tarihinde ekonomik ve toplumsal açısından önemli olayların görüldüğü bir dönem içerisinde yapılmıştır. McGregor kendiside dahil olmak üzere birçok yöneticinin davranışlarını gözlemleyerek lider davranışları konusunda önemli varsayımda bulunmuştur (Kurnaz, 2019:17). Bu varsayıma göre, liderlerin veya yöneticilerin davranışlarını belirleyen en önemli faktörlerden biri, onların insan davranışları hakkındaki varsayımları olduğunu öne sürmektedir (Koçel 2005: 594; Küçüközkan, 2015: 89). Mc Gregor'un geliştirdiği X yaklaşımı klasik yönetim yaklaşımının, $\mathrm{Y}$ yaklaşımı ise neo-klasik yönetim yaklaşımının yöneticiye yani lidere olan bakış açışını ifade etmektedir.

Tablo 6: McGregor'un X ve Y Yaklaşımı Lider Özellikleri

\begin{tabular}{|c|c|}
\hline X Yaklaşımı Lider Davranışları & Y Yaklaşımı Lider Davranışları \\
\hline $\begin{array}{ll}\text { - } & \text { İnsanlar edilgen ve pasiftir. } \\
\text { - Çalışanları yönlendirmek ve motive } \\
\text { etmek gerekir. } \\
\text { • } \\
\text { İnsanlar işi sevmez ve işten kaçmak } \\
\text { ister. } \\
\text { - Çalışanlar örgütsel amaçlar için } \\
\text { zorlanmalı ve denetlenmelidir. } \\
\text { - } \quad \text { Liderler otoriter tarzdadır. } \\
\text { Bu varsayımı temel alan lider, sıkı } \\
\text { kontrol, baskı ve cezalandırmayı } \\
\text { benimser. } \\
\text { - Liderler çalışanlar hakkında kötümser } \\
\text { bir düşünce benimsemektedir. }\end{array}$ & $\begin{array}{ll}\text { - } & \text { İnsanlar için iş oyun ve dinlenme kadar tabiidir. } \\
\text { - } & \text { İnsanlara sorumluluk yüklenebilir. } \\
\text { - } & \text { Her insan potansiyelini geliştirip aldığı } \\
\text { - } & \text { sorumlulukları çoğaltır. } \\
\text { İnsanlar kabullendikleri amaçlara hizmet ederken } \\
\text { kendilerini yönetebilir ve denetleyebilir. } \\
\text { - } \quad \text { Amaçlara bağlılık, elde edilmesi muhtemel } \\
\text { ödüllere bağlıdır. } \\
\text { - } \quad \text { Lider, iş görenlere yaratıcı ve kendilerini geliştirici } \\
\text { bir ortam sağlar. Bu nedenle lider demokratik } \\
\text { tarzdadır. } \\
\text { Liderler çalışanlar hakkında iyimser bir düşünce } \\
\text { benimsemektedir. }\end{array}$ \\
\hline
\end{tabular}

Kaynak: (Koçel, 2005: 594-595; Küçüközkan, 2015:89; Kurnaz, 2019: 17-18)

Sonuç olarak, davranışsal yaklaşımla liderler davranışları ve bu davranışsal yönelimlerin takipçileri üzerinde nasıl bir etkileşim süreci yaşatacağı incelenmiştir. Davranış teorileri, liderlik davranışlarının sadece görev ve ilişki boyutunu ele almış ancak liderlik sürecinin oluştuğu çevreye ve koşullara ağırlık verilmemiştir. Buda davranış teorilerinin ilk zayıf yönü olarak ele alınmaktadır. Diğer bir zayıf yönü ise liderin davranış tarzının koşullara göre değissebileceğinin göz ardı edilmesidir. Liderlik ile takipçilerinin tatmini ve verimi, faaliyet 
alanı, örgütsel hiyerarşik kademenin düzeyi gibi durumsal koşullar arasında bağlantı kurmadığı ve tek yönlü ilişki biçimini vurguladığ için 1960'lara doğru davranışsal liderlik yaklaşımı önemini kaybetmiştir (Köseoğlu, 2019: 33).

\subsubsection{Durumsallık Yaklaşımları}

1960'ların sonundan 1980'li yıllara kadar uzanan yirmi yıllık dönemde geliştirilen durumsallık yaklaşımı, en iyi lider özelliklerini veya davranışlarını belirlemenin ötesinde; bunların hangi durumlarda etkili olabileceğine yoğunlaşmışlardır (Köseoğlu, 2019: 33). Bu yaklaşıma göre yöneticilerin liderlik tarzlarının durumun gereklerine, yere ve zamana göre hatta yaşanan kriz dönemlerine veya örgütün hedeflerine göre biçimleneceği ve farklılaşacağı iddia edilmektedir.

Durumsallık yaklaşımını savunan araştırmacıların ortaya koyduğu temel görüş, etkili lider değişmez davranış özelliklerine sahip olmak yerine koşullara, gruba ve kişisel özelliklere göre farklılaşabilen davranışlar özelliklerine sahip liderdir. Bundan dolayıdır ki bu yaklaşımı benimseyen çalışmalarda en iyi tek bir liderlik davranışı veya tarzı değil, o durum için en etkin olacak liderlik davranışı hangisi ise onun uygulanması gerektiği savunulmaktadır (Alioğulları, 2019: 17). Durumsallık yaklaşımları içerisinde değerlendirilen pek çok çalışma bulunmaktadır. Bu çalışmalardan alan yazına önemli katkıları olan üç çalışma öne çıkmaktadır. Bunlar;

- Friedler'in Etkin Liderlik Yaklaşımı,

- House'un Amaç- Yol Yaklaşımı

- Vroom ve Yetton'un Liderlik Modelidir

Alan yazındaki bu yaklaşımların ortak noktası görev ya da ilişki ağırlıklı bir liderlik tarzının her durum ve koşulda geçerli olamayacağı görüşüdür. Bazı durumlarda görev merkezli bir liderlik tarzını başarıya götürebileceği, bazı durumlar da ise tersine ilişki merkezli bir liderlik tarzının verimli olacağı ve başarı getirebileceğidir ( Çağlar, 2004: 10).

\subsubsection{Friedler'in Etkin Liderlik Yaklaşımı}

Durumsal liderlik yaklaşımının ilk çalışmaları Eduard Fiedler'ın 1964 ve 1978 yıllarında doğal gruplarla gerçekleştirdiği (Kurnaz, 2019: 23) geniş çevrelerce kabul görmüştür. Bu yaklaşıma göre bir liderin başarısını etkileyen davranışları değerlendirmek ancak liderin içinde bulunduğu koşulları ve astların durumunu anlamakla mümkün olmaktadır (Kılıç, 2019: 21). Çalışmaları sonucunda liderin davranışlarının etkinliğini belirleyen üç durumsal faktör tanımlanmıştır. Bu faktörler (Koçel,2005: 598-602;Aksel, 2010: 45; Alioğulları, 2019: 18; K1lıç, 2019: 21);

1964 ve 1978 yıllarında doğal gruplarla gerçekleştirdiği seri araştırmalar sonrasında geliştirilen etkin liderlik modeli;

1- İşin Niteliği (Yapısı): Başarılmak istenen işin veya amacın tanımı, bu iş veya amaç için örgütün getirdiği kurallar, işi başarmak için ortaya atılan yol ve yöntemler ve örgütün iş akış süreçlerini içine almaktadır. Bu değişkenler örgütsel yapıya göre farklılık göstermektedir. Dolayısıyla bu yaklaşıma göre örgütlerde başarılmak istenen işler "planlanan" ve "planlanmayan" olarak ikiye ayrılmaktadır. 
2- Liderle Takipçileri Arasındaki İlişkiler: Lider ve takipçileri arasındaki ilişki olumlu olup güven ve saygıya dayanıyorsa bu ilişki "iyi”, lider ile izleyicileri birbirlerine güvenmiyorsa ve aralarında bir bağlılık bulunmuyorsa bu ilişki "zayıf" olarak nitelendirilmektedir. İyi bir ilişkinin olduğu durumda liderlik için olumlu bir ortam vardır ve liderin etkinliği söz konusudur.

3- Liderin Mevkisine Dayanan Otoritesinin Derecesi (Liderin Kontrol Gücü): Liderin otoritesini, yaptırım gücünü, çalışanlarını ödüllendirme, cezalandırma, işe son verme ve terfi ettirme imkânlarını ifade etmektedir. Bu yaklaşıma göre liderin mevkiye dayanan yetkilerinin fazla olduğu durum olumlu, az olduğu durum ise olumsuz olarak görülmektedir.

$\mathrm{Bu}$ üç faktörün aynı ana değerlendirilmesi ile liderlik davranışı belirlenmektedir. Bu liderlik davranışlarının model olarak gösterimi Şekil 2'de gösterilmektedir.

Fiedler' in durumsallık yaklaşımı sonuçlarına göre; en olumlu durum söz konusu olduğunda liderin takipçi grubu yönetilmeye hazırdır ve önderin yönlendirmesini beklemektedir. En olumsuz durumda ise liderin kişilere özel yönetim anlayışı benimsemesi halinde lider hiçbir sonuç alamayacaktır (Koçel, 2005: 602). Yani en olumsuz durumda da olumlu durumda da liderin doğrudan işe yönelik davranış sergilemesi kendisini daha başarılı yapacak ve dolayısıyla örgütü de hedefine daha iyi bir şekilde ulaştıracaktır.

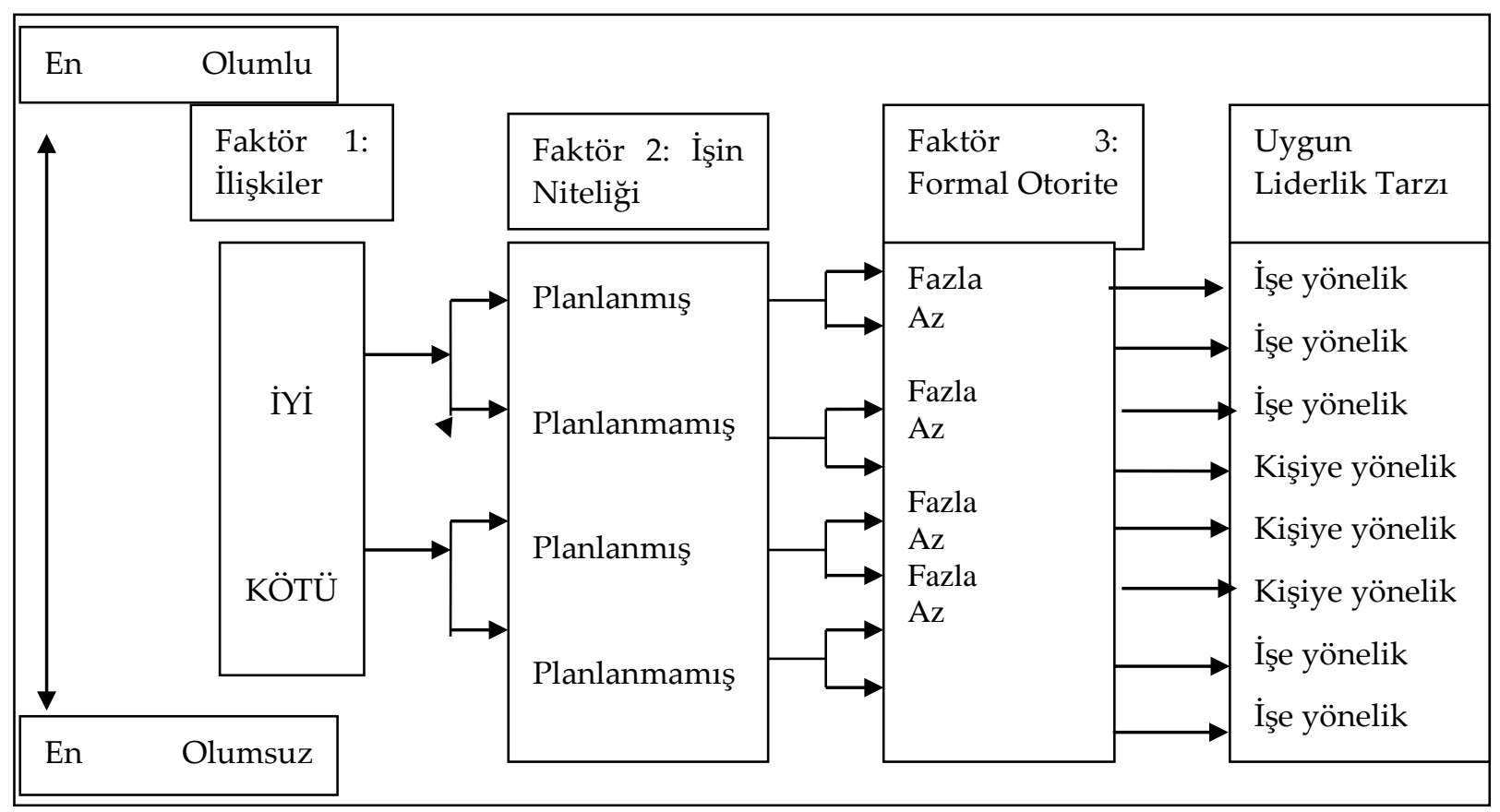

Şekil 2: Fiedler Liderlik Modeli Kaynak: (Koçel, 2005: 601)

\subsubsection{House'un Amaç- Yol Yaklaşımı}

Robert House ve Martin Evans tarafından geliştirilen bu yaklaşım genel olarak motivasyon teorilerinden bekleyiş yaklaşımına dayandırılmaktadır (Koçel, 2005: 602). Bu yaklaşımda liderin örgütsel amaçlara ulaşabilmesi için takipçilerini nasıl ve hangi davranışlarla motive edebileceği üzerinde durulmaktadır. Bu doğrultuda takipçilerin tatminini ve performansını 
artırmaya dayanan bir yaklaşımdır (Kurnaz, 2019: 24). Buna göre lider çeşitli durumlarda geçerli olacak dört farklı motive edici davranış sergilemektedir. Bunlar (House ve Mitchell, 1975: 9);

1- Otoriter Liderlik: Yapılacak işleri lider belirler, bu işeri takipçilerine dağıtır, beklentilerini açıklar, iş ile ilgili amaç ve ilkeleri açıklar, kurallar koyar ve bunlara uyulmasını ister. Takipçiler iş ile ilgili kararlara katılmaz.

2- Destekleyici Liderlik: Lider takipçilerin ihtiyaç, huzur ve mutluluğu nu önemser. Takipçileri ile arkadaşça ilişkiler kurmaya özen gösterir.

3- Katılımcı Liderlik: Lider örgüt ile ilgili karar alırken takipçilerinin karar verme sürecine katılmalarını önemser.

4- Başarı Odaklı Liderlik: Lider örgüt için önemli ve yüksek hedefler belirler ve bunların gerçekleşmesi için takipçilerini destekler ve motive eder.

Amaç-yol yaklaşımına göre lider iki farklı görevi söz konusudur. Bu görevlerden birincisi örgüt amaç ve hedeflerinin doğru şekilde tespit edilmesi ve bunların takipçilere veya çalışanlara aktarılmasıdır. İkincisi ise, takipçilerini amaçlar doğrultusunda iş ile ilgili gösterecekleri performans sonucu sahip olabilecekleri ödüllerin belirlenerek çalışanlara açık bir şekilde bildirilmesidir (Kurnaz, 2019: 24). Açılanan ödül sonucunda takipçilerin motivasyonu sağlanmış olduğu için Vroom'un bekleyiş yaklaşımının bir uzantısı olarak alan yazında yerini almıştır.

Bu yaklaşıma göre en uygun liderlik davranışının hangisi olduğu durumsal faktörlere göre değişmektedir. Lider davranışlarını etkileyen bu durumsal faktörler ise (Koçel, 2005: 604);

- Takipçilerin kişisel özellikleri

- Çevresel ve zamansal faktörler

- İşin niteliği olarak belirtilmektedir.

Yol-amaç yaklaşımına göre, çevresel faktörlerin belirsizlik derecelerine göre farklı liderlik modeli önermektedir. Belirsizliğin yüksek olduğu durumlarda yönlendirici liderlik, rutin işlerde ise destekleyici liderlik tavsiye edilmektedir (Köseoğlu, 2019: 40). Bu önerilerden de anlaşıldığı üzere, lider o andaki duruma uyabilecek en uygun liderlik davranışını gerçekleştirdiği takdirde başarılı olabilmektedir.

\subsubsection{Vroom ve Yetton'un Liderlik Modeli}

Victor H. Vroom ve Phillip W. Yetton tarafından 1973' de geliştirilmiş bu yaklaşım “Katılmalı Liderlik Teorisi" olarak da adlandırılmaktadır (Köseoğlu, 2019: 40). Bu yaklaşıma göre lider davranışlarıyla karar almaya süreci ve katılım süreci ilişkilendirilmektedir (Aksel, 2010: 54). Bu yaklaşım 1988 yılında Victor H. Vroom ve Arthur geliştirilmiş ve “Normatif Durumsallık Yaklaşımı" olarak son halini almıştır.

Çalışmalardan elde edilen sonuçlar doğrultusunda farklı durumlara göre 5 farklı karar alma davranışına ulaşılmıştır. Bunlar (Aksel, 2010: 54-55; Tunçer, 2012: 312 );

1. Otoriter Lider I: Lider kriz durumlarında sorunları kendi başına çözer ve Örgüt içinde kararları kendisi alır. 
2. Otoriter Lider II: Lider çözümlenecek sorunlar ile ilgili gerekli bilgiyi takipçilerinden alır ancak sorunun çözümü konusunda kendisi karar alır.

3. Danışmacı Lider I: Lider sorunları takipçileri ile tek tek paylaşır ve bireysel olarak çözüm yolları ve öneriler alır. Ancak kararları kendisi verir yani bu kararlar takipçilerin önerilerini içinde barındırabilir ya da barındırmayabilir.

4. Danışmacı Lider II: Lider sorunları takipçileri ile grup içinde paylaşmaktadır fakat kararları yine tek başına almaktadır.

5. Grup Lider II: Lider sorunları örgüt içindeki gruplar ile bir toplantı şeklinde paylaşır ve çözüm önerileri üretilmesini ister. Üretilen çzüm önerileri üzerinde tartışılarak bir uzlaşma ile karara bağlanmasını sağlar.

$\mathrm{Bu}$ yaklaşıma göre tek ve en iyi liderlik tarzı da tek ve iyi karar verme davranışında bulunmamaktadır. Her bir karar alma şeklinin avantajı olduğu gibi dezavantajı da bulunmaktadır. Durumsallık teorilerini genel olarak değerlendirecek olursak, bu yaklaşımlar liderleri serbest bırakmakta ve liderlere farklı durumlar söz konusu olduğunda o anki durumun özelliklerini çözümleme avantajı ile hareket etmeleri özgürlüğü vermektedir. Bu olumlu yanları yanında bazı eleştiriler de söz konusudur. İlk eleştiri ise liderin örgütün içsel koşulları içerisinde değerlendirmesi ve liderin etkililiğini örgütteki başarısı ile değerlendirmektedir. Oysaki günümüzde bir liderin başarısı, onun örgüt içindeki başarısı ile değil, örgütün bulunduğu çevresel şartlarla başa çıkabilme ve rekabet edebilme yeteneği gibi faktörlerle de ölçülmektedir (Köseoğlu, 2019: 42-43). Diğer bir eleştiri ise bu yaklaşımların hiç biri hangi durumda hangi liderlik veya karar alma tarzının uygulanacağı konusunda net bilgiler vermemektedir.

\subsection{Güncel Liderlik Yaklaşımları}

Küreselleşme ile tüm dünyanın tek bir pazar haline dönüşmesi, örgütlerin rekabet gücünün güçlendirilmesi gerekliliği, tüm dünyada yaşanan teknolojik gelişmeler ve sosyo kültürel yenilikler sebebi ile liderlik anlayışlarının da bu sürece ayak uydurmasını gerekli kılmıştır. $\mathrm{Bu}$ süreçte değişimi görebilen ve bu değişime ayak uydurabilen liderlerin başarılı olması kaçınılmaz bir hal almıştır ( Paksoy, 2010: 26). Dünyada yaşanan bu değişime ayak uydurabilmenin önemli koşulu liderlerin farklı kültürlerin özelliklerini özümseyerek farklı kültürlerdeki insanların düşünce, tutum ve davranışlarını etkileyebilmekten geçmektedir (Çalışkan, 2010: 271). Bu nedenle son dönemlerde liderlik konusunda yapılan yeni araştırmalar özellikle örgüt kültürünü geliştirme ve değişimi yönlendirme üzerinde yoğunlaşmaktadır (Köseoğlu, 2019: 43-44).

Dünyada ve yönetim alanında yaşanan gelişmeler liderlik alalında da yeni yaklaşımların ortaya atılmasına ve yeni çalışmaların bu yönde ilerlemesine neden olmuştur. Bu bölümde de son dönemde liderlik alanında ortaya atılan bazı yeni yaklaşımlar üzerinde durulacaktır.

\subsubsection{Etkileşimci (İşlemci) Liderlik Yaklaşımı}

1970'lerin sonlarında Burns tarafından öne sürülmüş ve sonraki çalışmalar ile de geliştirilmiştir (Alioğulları, 2019: 32). Alan yazında etkileşimsel, sürdürücü, iş gördürücü veya transaksiyonel liderlik tarzı olarak adlandırılmaktadır (Kurnaz, 2019: 30) 
Bu liderlik tarzında lider ve takipçileri arasında bağımsız bir amaca ulaşmak adına değiştokuş ilişkisi söz konusudur. Takipçilerin rol ve görevleri açı şekilde belirtilmiştir ve amaca ulaşmak adına liderin görevi takipçilerine yol göstermek ve onları motive etmektir. Lider kurallara uyum ve yüksek performans gibi amaca ulaştırıcı olumlu davranışları ödüllendirmektedir. Kurallara karşı gelme ve düşük performans gibi olumsuz davranışları ise cezalandırmaktadır (Tunçer, 2012: 315). Bu tip liderler para ve statü verme gibi ödülleri motivasyon aracı olarak kullanmayı tercih etmektedir. Ayrıca etkileşimci lider kurumda yerleşik olan kültürü korumak isteğindedir. Bu tip liderler değişim, yenilenme, stratejik ve uzun vadeli planlar yapmayı tercih etmedikleri gibi kurumun kârlılık ve pazar payı gibi sayısal verilerini daha fazla önemserler (Eren, 2014: 464). Özetlenecek olur ise etkileşimci liderlik, ödüller vasıtasıyla çalışanların lideri izlemesini amaçlayan, çalışanların kurumsal kurallara tam anlamıyla uyması ve sadece ufak çaptaki genel dönüşümleri gerektiren bir liderlik tarzidır (Kurnaz, 2019: 31).

Etkileşimci liderlik, lider ve takipçileri arasındaki ilişkiler üzerine yoğunlaşmış bir liderlik tarzıdır ve geleneksel yönetimin fonksiyonlarını taşımaktadır. Lider takipçilerini güdüleyerek performanslarını yükseltmelerini sağlamak liderin en önemli görevidir. Bu sayede belirlemiş olduğu örgütsel amaç ve hedeflere ulaşma başarısı artmaktadır (Okçu, 2011: 443-444).

\subsubsection{Dönüşümcü Liderlik Yaklaşımı}

Dönüşümcü liderlik yaklaşımı 1978 yılında J. M. Burns tarafından sistemli bir şekle getirilmiştir. 1980 sonrasında da birçok liderlik araştırmasının odağında yer almaktadır (Doğan, 2018: 109). Etkileşimci lider yaklaşımının tam karşıtı bir yaklaşım olarak ortaya atılmıştır. Bu yaklaşıma göre lider, takipçilerinin değer yargılarını inançlarını ve düşüncelerini değiştirebilen kişidir. Aynı zamanda dönüşümcü lider, örgütlerde değişim ve yenilenmeyi gerçekleştirerek yüksek performans ile çalışmasını sağlayan kişidir (Koçel, 2005: 605).

Dönüşümcü liderler ödül verme ile takipçilerini motive etmek yerine onların kendini anlamasını ve ona güvenmesini sağlayarak başarı sağlayarak örgütünde büyümesine olanak sağlamaktadır. Takipçilerinin kişisel büyüme ve gelişimini de örgütün büyüme ve gelişimi kadar önemsemektedirler ( Güney, 2001: 297). Cesaret ve risk alabilme dönüşümcü liderin en dikkat çeken özelliklerindendir (Doğan, 2018: 111). Dönüşümcü liderlik değişime yönelik bir liderlik tarzı olması nedeniyle özellikle kriz dönemlerinde ve karmaşık yapıya sahip örgütlerde ön plana çıkmaktadır (Çalışkan, 2010:267). Ayrıca dönüşümcü liderler, takipçilerinin ihtiyaçlarının farkındadır ve bu doğrultuda takipçilerine yön verir. Aynı zamanda takipçilerinin mevcut potansiyel güç ve yeteneklerinin de farkındadır ve bunların kullanılması konusunda takipçilerini motive etmektedir (Okçu,2011: 427-428).

Okçu (2011) ise dönüşümcü liderlerin özelliklerini; ortak vizyon oluşturma ve paylaşma, zihinsel uyarım ve yaratıcılık, karizmatik etkiye sahip olma, etkili iletişim ve yüksek motivasyon becerisi, değişimin temsilcisi olma, duygusal dayanıklılık, cesaret ve risk alma, takipçilerini güçlendirme ve yetkilendirme, esnek yönetim anlayışı olarak sekiz madde ile özetlemiştir.

Dönüşümcü liderliğin günümüz örgütlerinin içinde bulunduğu koşullar dikkate alındığında küreselleşme koşulları, rekabetin yoğun olarak hissedilmesi, teknolojik ilerlemelerin her gün 
artarak yoğunlaşması gibi hızlı değişim ortamında daha etkili bir liderlik yaklaşımı olduğu söylenebilir. Çünkü dönüşümcü liderlik yaklaşımı, geleneksel görüşün ötesinde, geleceğe yönelik vizyon kazandırıcı liderlik biçimini vurgulamakta ve bu sayede söz konusu değişimlere örgütün daha kolay ayak uydurmasına olanak sağlamaktadır (Köseoğlu, 2019: 48). Bass (1985) çalışmasında dönüşümcü liderliğin ilham verme, karizma, entelektüel teşvik ve bireysel ilgi olmak üzere dört alt boyuttan oluştuğunu belirtmiştir (AKT: Alioğulları, 2019: 29).

\subsubsection{Vizyoner Liderlik Yaklaşımı}

1980'li yıllar ile yeni liderlik yaklaşımlarına yönelen araştırmacılar 1990 sonrasında liderin vizyon sahibi olması boyutunu ön plana çıkardıkları yeni bir liderlik yaklaşımı olan vizyoner liderlik yaklaşımı üzerinde durmuşlardır. Vizyoner liderin en önemli özelliği olarak örgütlerin değişime ayak uydurmasını sağlayarak onları geleceğe yönelik belirsizliklerden koruması olarak belirtilmektedir (Çelik, 1997: 468; Doğan, 2018: 99). Bu nedenle de vizyoner lider yeni bilgiler konusunda her zaman açık ve isteklidir çünkü her yeni bilginin yeni bakış açları getirerek örgütü geleceğe karşı daha güçlü kılacağını bilmektedir. Ayrıca vizyoner liderlerin ikna güçlerinin de çok yüksek olması sayesinde takipçilerini ortak hayaller çerçevesinde birleştirebildikleri, sabırlı ve ısrarcı oldukları yapılan çalışmalarda belirtilmektedir (Yeşil: 2019: 165-166).

Çelik (1997) çalışmasında vizyoner liderliğin üç önemli rolü olduğunu belirtmektedir. Bunlar;

1. Yolu Görmek: Yol, vizyonun gelecekteki görüntüsüdür. Ulaşılması gereken hedeftir. Vizyoner lider, alternatif yollardan hedefine ulaşmada en uygun yolu görebilir. Vizyoner lider düşünce, bilgi ve sezgi gücüyle geleceğin gizemli dünyasının perdesini aralar ve geleceğe işık tutar.

2. Yolda Yürümek: Vizyoner liderin kararlılığım göstermektedir. Vizyoner lider, yolu görmenin yanında gördüğü yolda başarılı bir şekilde yürüyebilen ve ilerleyebilen liderdir.

3. Yol Olmak: Vizyonuyla insanları arkasından sürükleyen kişiler vizyoner liderdir. Takipçileri vizyoner liderin açmış olduğu yolda ilerleyerek örgütü başarıya ulaştırmaktadır.

\subsubsection{Karizmatik Liderlik Yaklaşımı}

1980'li yıllardan sonra güncel liderlik yaklaşımlarının ön plana çıkmasıyla yaygınlık kazanan karizmatik liderlik kavramına göre liderler; genellikle astlarının motivasyon ve tatminlerini yükseltebilen bir yönlendirebilme yeteneğine sahip kişilerdir. Karizma kelime anlamı olarak başkalarını kişisel çekicilik temelinde etkileme ve yönlendirme yeteneği olarak görülmektedir. Karizma sadece liderin kişilik özelliklerinden biri değil aynı zamanda çalışanların lidere verdikleri tepkilerde ve bağlılıkta da saklıdır. Bu kapsamda karizmatik liderlere sahip gruplarda çalışanlarda performans artışı, lidere bağlılık, lider fikirlerine aşırı saygı, sadakat ve grup amaçları için kişisel amaçlardan vazgeçme gözlemlenmektedir (Çalışkan, 2010: 267;Kurnaz, 2019: 37). Bu liderler her zaman bir vizyona ve amaca sahiptir. Güçlü oldukları yanlarının farkındadırlar ve bunun üzerine yatırım yaparlar (Alioğulları, 2019: 33).

Karizmatik liderler insanları kolay etkileme özelliğini kullanarak takipçilerini kendi istediği hedeflere kolaylıkla yönlendirebilirler (Çağlar, 2004: 10). Karizmatik liderler kriz ve benzeri 
zor zamanlarda kendini gösteren olağanüstü nitelik ve kişiliğe sahiptir. Bu bağlamda dünya tarihinde önemli rol oynamış M. K. Atatürk, M.Luther King, Hitler ve Gandhi gibi liderler karizmatik lider olarak verilebilecek en güzel örneklerden olacaktır (Güney, 2001: 299). Zor ve kriz dönemlerinde ortaya çıkmaları nedeni ile karizmatik liderlerin takipçilerinin kendilerini bu zor dönemden kurtaracaklarına inanmaktadırlar. Tüm bunlar dikkate alındığında karizmatik liderlerin en belirgin özellikleri, öz güvenleri yüksek, etkileme ve hitabet gücüne sahip olmaları ve risk almaktan kaçınmamalarıdır (Bektaş, 2016: 48).

Dünya çapında yapılmış olan birçok çalışmanın sonuçları karizmatik liderlerin karizmatik olmayan liderlere göre daha etkin ve başarılı olduklarını göstermektedir (Çalışkan, 2010: 267).

Conger ve Kanungo (1988) karizmatik liderlik üzerine en ayrıntılı analizleri yapan araştırmacılardır. Çalışmalarında karizmatik liderleri karizmatik olmayanlardan ayıran özelliklerden söz etmektedir. Bunlar;

- Kendine güven

- Vizyon sahibi olma

- Kendi vizyonlarını kolaylıkla ifade edebilme

- Vizyonlarına güçlü bir şekilde inanma

- Sıra dışı davranışlar

- Değişimi benimseme ve değişiim ajanı gibi görünme

- Çevreye duyarlılık olarak ifade edilmektedir.

Bennis (2011) Amerika Birleşik Devletlerindeki 90 lider üzerine yapmış olduğu çalışmasında ise dört ortak özelliğe rastladı̆̆ını belirtmektedir. Bunlar;

- Zorlayıcı bir vizyonu ve hedeflediği bir amacı vardır,

- Kendi vizyonlarını takipçilerinin kendileri ile özdeşleştirmelerini sağlamaktadırlar,

- Vizyonlarına ulaşmak adına tüm imkânları kullanır, buna önem verir ve bu yolda tutarlılık gösterirler

- Kendi güçlü yönlerini bilir ve bu güçlü yönleri üzerine yatırım yaparlar.

\subsubsection{Antrenör Tipi Liderlik}

Yol gösterici liderlik veya koçluk olarak da adlandırılmaktadır. Bu tip liderlik çok farklı özellik, yetenek ve ilgi alanlarına sahip kişileri bir araya getirerek bir grup oluşturan ve amaç ve hedeflere ulaşmak için bu grup üyelerini başarı için cesaretlendiren, sorumluluklarını yerine getirmeleri için yönlendiren kişi olarak tanımlanmaktadır (Tunçer, 2012: 320). Güney (2001) ise kişilerin yeteneklerini ortaya çıkarmak adına takipçilerine yardımcı olan liderlik tarzı olarak tanımlamaktadır. Bu tanımların ortak noktası takipçilerini eğitmek, cesaretlendirmek ve yol göstermeleridir.

$\mathrm{Bu}$ tip liderlikte çift taraflı iletişim ve güven çok önemlidir. Lider takipçileri ile sürekli iletişim içindedir. Liderin rolü işi kontrol etmek yerine takipçilerinin gelişmesi ve eğitilmesi için destek olmaktır (Tunçer, 2012:320-321). Antrenör tipi liderlik, takipçilerini karşılaştıkları örgütsel güçlükleri aşma ve çözme konusunda eğiten ve yol gösteren bir liderlik yaklaşımı sergilemektedir. Aynı zamanda antrenör tipi lider takipçilerinin doğru olmayan davranışlarını tespit edip düzeltme yolunda onlara tavsiyelerde bulunmaktadır (Çelik,2011: 15). Bu tip liderlikte psikoloji ve pedagoji bilgisi çok önemlidir. 
Etkili bir antrenör tipi liderde bulunması gereken bazı özellikler; Empati yeteneği, iyi bir dinleyici olma, insanları tanımak ve onlar hakkında hüküm verme, diplomasi bilgisi ve incelik, insanlara karşı sabırlı olma, takipçilerinin refah ve mutluluğu ile yakından ilgilenme, insanlara karşı düşmanca tavırlardan uzak olma, kendine güven ve duygusal dengeye sahip olma, kendi ekip üyeleri ile rekabette bulunmama ve insanlar için en iyi ve doğruyu arama ihtiyacı olarak belirtilmektedir ( Güney, 2001: 302).

Günümüz örgütlerinde yoğun olarak ekiplerin oluşturulmuş olması nedeni ile bu tip liderliğe daha çok ihtiyaç duyulmaktadır. Antrenör tipi lider, yöneticilik yapmanın yanında kendine bağlı olan ekiplerin çalışmalarını kolaylaştırır ve yeni ortamlar hazırlar. Ortaya çıan engelleri ortadan kaldırarak şeklinde ekibine destek sağlamaktadır. Liderin daima en iyiyi bildiği mükemmeliyetçi bir varsayım kabul görmemektedir. Bu tip liderliğin başarısı için örgüt kültürünün bu yönde yapılanmış olması ve takipçilerinin yeni şeyler öğrenmeye açık olması gerekmektedir (Çelik, 2011: 15-16; Tunçer, 2012: 321).

\section{SPOR YÖNETIMIINDE LİDERLIKK}

Liderlik, yönetim alanında olduğu gibi, spor sektöründeki gerek oyun alanındaki uygulamalarda gerekse de spor ile ilgili diğer faaliyetlerde anahtar faktör ve ayırt edici özelliklerden birisidir (Gündoğdu, 2014: 51). Spor kurumları ve organizasyonlarının kuruluşunu, işleyişini ve spor faaliyetlerinin en iyi şekilde yürütülmesini sağlayan spor yönetimi için de liderlik özellikli bir öneme sahiptir. Spor politikalarının ulusal ve uluslararası düzeyde uygulanması ve başarılı bir şekilde yürütülmesinde spor yöneticileri çok önemli rol oynamaktadır. Spor yöneticiliği, sporun genel amaç ve ilkeleri doğrultusunda önemli vasıflar ve hem alanı ile ilgili hem de yönetimsel anlamda bilgi gerektiren bir meslektir (Yetim, 1996: 87). Bu vasıflardan bir tanesi ve en önemlisi ise astlarına, sporculara ve çevresindeki insanlara örnek bir lider olmaktır (K1lınç, 2013: 21).

Sporun sosyal bir olgu olması ve hedef kitlesinin de insan olması nedeniyle spor yöneticiliğinde yöneticilerin liderlik özelliklerine sahip olması gerekliliği daha da ön plana çımaktadır (Yetim, 1996: 92). Özellikle rekabet ve başarının çok ön planda olduğu spor sektörü için, iyi bir yönetici olmak yanında liderlik özelliklerine sahip bir spor yöneticisinin hem ulusal hem de uluslararası platformlarda rekabet gücü artmakta ve başarıyı yakalamasını kolaylaştırmaktadır. Spor yöneticilerinin hangi durumlarda hangi liderlik stillerini uygulayacaklarını veya kendilerinin hangi liderlik özelliklerinin baskın olduğunu bilmeleri, takipçilerini etkileme ve başarıya ulaşma açıcından önemli olacaktır (Gündoğdu,2014: 52).

Spor alanında çalışan bir liderin öncelikli olarak sahip olması gereken özellikler; yetki verme becerisi, takipçilerine vizyon kazandırma becerisi, kendini organizasyon ve grubun ortak amaçları için adama becerisi, toplumsal, örgütsel ve kültürel değerlere saygı becerisi, karşılaşılabilecek risklere karşı öngörü ve sezgi becerisi şeklinde ifade edilebilir (Gökçe, 2005: 66). Küreselleşmenin etkilerinin yoğun olarak hissedildiği günümüzde başarılı bir spor yöneticisinin, çalışanlarına ilgili, güvenilir, takipçilerine ve sporculara coşku ve ilham verebilen ve bu sayede onları etkileyebilen bir liderlik tarzını benimsemesi gerekmektedir (Gündoğan, 2014: 52). Lider, takım veya organizasyon içerisinde arkadaşlık ve dostluk kavramını ön planda tutarak aidiyet duygusunu arttırmalıdır (Terlemez, 2019: 150). Bunun yanında başarma arzusunun yoğun olarak görüldüğü spor alanında liderlerin hırslı ve 
azimli olmasıyla birlikte sabırlı olmaları ve eğitime ve gelişmeye açı olmaları gerekmektedir.

Spor alanındaki liderlik tanımlarını incelendiğinde, "Spor sektörü içerisinde yer alan bireyleri ve grupları hedef ve amaçları doğrultusunda yönlendiren ve davranışlarına etki eden bir süreç" olarak belirtilmektedir (Çelik 2016: 63). Donuk (2006) lideri örgüt üyelerinin kapasitelerini maksimum kullanmalarını sağlayan ve bunun için ortam hazırlayan takipçilerini motive eden kişi olarak tanımlamaktadır. Alan yazında spor alanında liderlik dendiğinde antrenör (çalıştırıcı) ön plana çıkmaktadır. Ancak spor sektörü çok karmaşık ve farklı alanları da içine alan bir yapıya sahiptir. Sporda liderlik dendiğinde antrenörler dışında spor kulüplerinde kulüp yöneticileri, federasyonlarda federasyon başkanı ve alt birimlerin yöneticileri, Türkiye Olimpiyat Komitesi başkan ve üyeleri, medya alanında spor haberleri yöneticileri ya da il teşkilatlarında gençlik ve spor müdürlüğü yöneticileri, federasyon il temsilcileri ve il hakem kurulu başkanları ya da spor merkezleri ve organizasyonları yöneticileri gibi birçok örnek verilebilmektedir.

Spor alanında yapılan Türk alan yazını incelendiğinde, sporda liderlik kavramını ele alan az sayıda çalışma bulunmaktadır. Kocamaz Adaş ve ark. (2019) spor örgütlerinde çalışanların liderlik kavramına ilişkin algılarının incelendiği çalışmalarında katılımcıların en sık tekrarladıkları kavramların; yol göstermesi, bilgili ve tecrübeli olması ve etkilemesi olarak belirtilmiştir. Bu çalışmadan yola çıkarak spor alanında liderlerin yol gösterici, alanında bilgi ve tecrübeye sahip olman kişiler olması ve takipçilerini etkilemesi önemli özellikleri arasında sayılabilir.

Gündoğdu ve Sunay (2018) çalışmalarının sonuçlarına göre spor yöneticilerinin baskın olarak dönüşümcü liderlik sergiledikleri tespit edilmiştir. Spor sektöründeki yöneticilerin kendilerini dönüşümcü lider olarak tanımlamaları ülkemiz adına olumlu ve önemli bir sonuç olarak değerlendirilmektedir. Kandemir, (2017) antrenörler üzerine yapmış olduğu çalışma sonuçlarına göre, kadın antrenörlerin erkek antrenörlere göre daha demokratik bir tutum sergiledikleri belirtilmiştir. Ayrıca bireysel spor dallarındaki antrenörlerin antrenman ve eğitimine önem veren, daha eğitici ve demokratik liderlik tarzı gösteren ve gerektiği zamanlarda otokratik davranış sergileyen liderlik tarzlarına sahip oldukları belirtilmiştir. Çelik (2011) çalışmasında oyuncular gözünden antrenörlerinin liderlik özelliklerini açıklamaya çalışmıştır. Oyuncularının ihtiyaçlarını önemseyen antrenörlerin güvenilir, risk alan ve bunu söylemleri ile destekleyen antrenörlerin de etkileyici liderlik vasıflarına sahip oldukları görülmektedir.

Şirin (2008) Spor Bilimleri alanında eğitim veren yüksekokul müdürleri üzerine yapmış olduğu çalışmasında; çalışmaya katılan müdürlerin dönüşümcü veya etkileşimci liderlik tarzlarının özelliklerini gösterdikleri belirtilmektedir. Donuk (2006) antrenörler ve sporcular ile yapmış olduğu çalışmasında liderlik tarzlarını incelemiştir. Çalışma sonuçlarına göre bu çalışmaya katılım sağlayan antrenörlerin; sporcularının eğitim ve öğretimine önem veren, onlara sosyal destek sağlayan, yarı demokratik, yarı otokratik bir liderlik tarzlarının oldukları tespit edilmiştir. Sporcuların görüşlerine bakıldığında ise antrenörlerinin daha çok demokratik olmalarını istedikleri belirtilmektedir. Antrenör ile sporcu ilişkisinde, antrenörün liderlik tarzı sporun rekabetçi doğasıyla ve sporun motivasyon ve bireysel farklılık gerektiren yanı itibariyle sporcuya yani kişiye yönelik olmak zorundadır (Özdinç, 
2014: 100). Önemli olan antrenörün liderlik tarzı açısından kendisini tanıyarak sahip olduğu liderlik tarzını bilmesi ve bunu sporcularının özelliklerine göre değiştirebilmesidir (Temel,2010: 121).

Gökçe (2005) ise farklı görevlerde yer alan spor yöneticilerinin liderlik tipleri üzerine yapmış olduğu çalışma sonuçlarına göre; Gençlik ve Spor İl Müdürlüklerinde görev yapan spor yöneticilerinin statükocu ve görevci liderlik boyutları yüksek, özel kulüplerde görev yapan spor yöneticilerinin ise ilişkisel liderlik boyutunun yüksek olduğu belirtilmektedir. Mızrak ve ark (2004) Gençlik ve Spor Genel Müdürlügünde ve federasyonlarda görev yapan genel sekreterlerin liderlik tarzları araştırılmıştır. Çalışma sonuçlarına göre ağırlıklı olarak işe yönelik liderlik tarzı, yani klasik yönetim anlayışı çerçevesinde liderlik tarzı benimsedikleri belirtilmiştir.

\section{SONUÇ}

Günümüzde sürekli değişim ve gelişim içerisinde olan sosyal ve ekonomik koşullar örgütlerde çalışan veya yer alan bireylerle sağlıklı iletişime geçebilmeyi, etkin ilişkiler kurabilmeyi ve grup şeklinde çalışabilmeyi gerekli kılmaktadır. Aynı zamanda kişiler de kendi istek, ihtiyaç ve amaçlarını gerçekleştirmek ve sosyalleşebilmek için bir gruba dâhil olmaktadır. İnsanlar grup halinde yaşayan sosyal nitelikli canlılar oldukları kadar oluşturdukları grupları yönetecek ve hedeflerine götürecek liderlere ihtiyaç duymaktadırlar $\mathrm{Bu}$ doğrultuda oluşturulan gruplarda, liderler kişileri hedeflerini gerçekleştirmek için motive etmektedir. Bu durumda örgütsel ve kişisel hedeflerin gerçekleşmesi yolunda liderin özellikleri ve başarısı öne çıkmaktadır. Liderin örgüt içindeki önemi nedeni ile yönetim alanında en çok tartışılan ve araştırılan konular arasında yer almaktadır.

Alan yazın incelendiğinde ortaya atılmış yaklaşımlara genel olarak bakılacak olur ise, geleneksel liderlik yaklaşımlarından olan özellikler yaklaşımı liderin diğer grup üyelerinden ayrılan kişisel ve fiziksel özelliklerine odaklanmıştır. Sadece lider özelliklerine odaklanmanın yetersiz olduğu görüşüne varılması sonucunda liderin davranışlarına ve bu davranışların sonuçlarına ve gruplar üzerindeki etkilerine odaklanılmıştır. Spor yönetiminde çalışan kişilerin de liderlik vasıfları açısından değerlendirme yapıldığında, sadece spor yöneticisinin veya liderinin kişisel özelliklerine bakılarak değerlendirme de bu anlamda yetersiz olacaktır. Spor camiasında çalışan yöneticilerin kişisel özellikleri, lider olmaları bakımından yeterli nitelikler olarak değerlendirilemez.

Davranışsal liderlik yaklaşımları da etkili ve etkisiz liderlik arasındaki farkları açıklamaktadır. Özellikler yaklaşımının tersine, liderliğin sadece doğuştan gelen özellikler ile olmadığı, eğitim ve yaşantılar yolu ile liderlik davranışının öğrenilebileceği sonucuna varılmıştır. Bu durumda liderin kişiliği yanında göstereceği davranışlar da değerlendirmeye alınmıştır. Spor yönetimindeki kişilerin göstereceği davranışlar da bu anlamda önemlidir. Bu durumda işe yönelik davranış önemli olmakla birlikte insana yönelik davranışlara odaklanmak, spor alanında daha önemli sonuçlar doğurabilecektir.

Davranışsal liderlik çalışmaların sonrasında araştırmacılar, lider ve örgüt çevresine yönelmiş ve araştırma sonuçlarında, durumsallık yaklaşımları ortaya atmışlardır. Durumsallık yaklaşımı araştırmaları sonucunda en iyi olarak gösterilebilecek liderlik tarzının olmayacağı anlaşılmıştır. Liderlerin içinde bulundukları zaman diliminin, örgütün ve takipçilerinin 
özelliklerinin lider davranışlarını etkilediği sonucuna varılmıştır. Spor yöneticilerinin başarılarında da bu durumsal faktörler büyük öneme sahiptir. Spor sektöründe çalışan liderin kendi kişilik özellikleri, gösterdiği davranışlar, yönettiği takımın özellikleri, çevresel faktörler durumsallık faktörlerini oluşturmakta ve sporcuların başarılarında büyük etkiye sahip olabilmektedirler.

1980 sonrasında dünyada yaşanmakta olan ekonomik gelişme ve süreçler ile güncel liderlik yaklaşımları yönünde çalışmalar yoğunlaşmış ve dönüşümcü, etkileşimci, vizyoner, karizmatik, atrenör tipi lider gibi yeni liderlik tarzları özgünlük kazanmış ve bu yönde çalışmalara devam edilmektedir. Bahsedilen bu liderlik tarzlarından hangisi benimsenmiş olursa olsun takipçilerin liderlerinden genel olarak benzer beklentileri olduğu yadsınamayacaktır. Bu beklentiler, liderlerinin kendilerine adaletli bir şekilde davranması, liderlerine güven duyma isteği, örgütün tamamını kapsayıcı olması ve paylaşımcı ve öğretici olmasidir.

Geleneksel liderlik tarzlarında yönetim hiyerarşik bir yapıdadır ve lider işi en iyi bilen kişi konumundadır. Ayrıca yönetim kararları alınırken takipçilerin görüşlerine ihtiyaç duyulmamakta ve takipçiler yeni ürün yaratılmasına katkıda bulunmamaktadır. Ancak günümüzdeki teknolojik ilerlemeler ve artan rekabet koşullarında liderlerin rolü değişmiştir. Liderler kendi başarılarının takipçilerinin verimliliğinin ve başarısının artmasıyla ve onlarında yönetim kararlarında söz sahibi olmasıyla olacağının farkındadırlar.

Güncel liderlik yaklaşımlarında, liderin takipçileri olan ilişkiler de önem kazanmaktadır. Spor alanında görev alan liderlerin spor takımlarının ve organizasyonlarının yönetiminde birçok zorlukla karşılaşmaktadır. Ayrıca spor alanındaki liderler, kendi bilgi ve becerilerini aktarırken görevleri dişına çıkarak sporcuların ve ailelerinin psikolojik durumlarını da yönetmesi gerekmektedir. Spor alanında görev alan liderlerin takipçilerini tek tek ele alarak, onlara değer veren ve destek olan aynı zamanda iletişimi güçlü liderlik tarzına sahip olmaları önemli bir başarı göstergesidir. Spor alanında da diğer alanlarda olduğu gibi liderlik fonksiyonları yüksek yöneticilere ihtiyaç duyulmaktadır. Spor yöneticilerinin liderlik vasıflarını örgütlerinde çağdaş yönetim anlayışı doğrultusunda etkili ve verimli bir biçimde kullanabilmeleri ile başarı sağlamaları mümkün olabilir.

Spor yöneticilerinin gösterebilecekleri liderlik tarzları arasında modern liderlik tarzlarının daha etkin olduğu ve başarıyı getireceği belirtilebilir. Özelikle spor yöneticilerinin başarısında dönüşümcü liderliğin ayrı bir yeri bulunduğu söylenebilir. Çünkü bu liderlik tarzı hem liderin yüksek kabiliyetlere sahip olmasını gerektirmekte, hem de izleyicisine ilham vererek onu güçlendirmesi ve hayallerini gerçekleştirebilmesi için gerekli yol ve yöntemleri izlemesi ile ilgilidir.

$\mathrm{Bu}$ çalışmanın sonunda, spor alanında çalışan kişilere, modern liderlik tarzlarını iyi öğrenmeleri ve yönettikleri ekiplerinde bunları uygulayacak teknikleri öğrenmeleri tavsiye edilebilir. Ayrıca spor alanında yapılacak olan liderlik çalışmalarında, modern liderlik anlaysşlarına yer verilerek spor sektöründe yer alan liderlerin (kulüp yöneticileri, antrenörler, il temsilcileri, federasyon sorumluları gibi) liderlik tarzları yönünden incelenerek alan yazına farklı çalışmalar kazandırılabilinir. Alan yazındaki spor alanında yapılmış çalışmalar içerik analizleri gibi nitel verilerle derlenerek spor sektöründeki liderlik 
tarzları açısından alan yazına önemli katkılar sağlanabilir. Ayrıca bu alanda nicel araştırmalar yapılıp sporcular için gerekli olan liderlik tarzları belirlenebilir.

\section{KAYNAKÇA}

Ağlargöz, O. (2012). Yetki, Güç ve Liderlik. C. Koparal içinde, Yönetim ve Orgaizasyon-1 (s. 4065). Eskişehir: Anadolu Üniversitesi Yayınları.

Aksel, İ. (2010). Liderlik Teorileri. C. Serinkan içinde, Liderlik ve Motivasyon Geleneksel ve Güncel Yaklaşımlar (s. 33-61). Ankara: Nobel Yayım Dağıtım.

Alioğulları, Z. D. (2019). Liderin Politik Becerisi, Lider - Üye Etkileşimi, Etik Liderlik ve Bazı İş Sonuçları arasındaki ilişkiler. Atatürk Üniversitesi, Sosyal Bilimler Enstitüsü, İşletme Anabilm Dalı, Basılmamış Doktora Tezi . Erzurum.

Bass, B. (1990). Bass \& Stogdill's Handbook of Leadership: Theory, Research and Managerial Applications. New York: The Free Press.

Bektaş, Ç. (2016). Liderlik Yaklaşımları ve Modern Liderden Beklentiler. Selçuk Üniversitesi Akşehir Meslek Yüksekokulu Sosyal Bilimler Dergisi , 2 (7), 43-53.

Blake, R. R., \& Moutun, J. S. (1966). Managerial Facades. SAM Advanced Management Journal , 31 (3), 30-37.

Cevrioğlu, E. (2007). Lider-Üye Etkileşimi ile Bireysel ve Örgütsel Sonuçlar Arasındaki İlişki: Ampirik Bir İnceleme. Afyonkarahisar Kocatepe Üniversitesi, Sosyal Bilimler Enstitüsü (Basılmamış Doktora Tezi) . Afyonkarahisar.

Conger, J. A., \& Kanungo, R. N. (1988). The Empowerment Process: İntegratig Theory and Practice. Academy og Management Review , 13 (3), 471-478.

Çağlar, İ. (2004). İktisadi ve İdari Bilimler Fakültesi Öğrencileri ile Mühendislik Fakültesi Öğrencilerinin Liderlik Tarzına İlişkin Eğilimlerinin Karşılaştırılmalı Analizi ve Çorum Örneği. Gazi Üniversitesi Ticaret ve Turizm Eğitim Fakültesi Dergisi , 2, 1-18.

Çalışkan, E. N. (2010). Çokuluslı İşletmlelerde Motivasyon ve Liderlik. C. Serinkan içinde, Liderlik ve Motivasyon Geleneksel ve Güncel Yaklaşımlar (s. 255-273). Ankara: Nobel Yayın Dağıtım.

Çelik, V. (1997). Eğitim Yönetiminde Vizyoner Liderlik. Kuram ve Uyguşlamalı Eğitim Yönetimi , $3(4), 465-474$.

Çelik, V.O. (2011). Basketbol Oyuncularının Görüşlerine Göre Antrenörlerin Karizmatik Liderlik Özelliklerinin Takım Bütünlüğüne Etkisi. Anadolu Üniversitesi, Sağglk Bilimleri Enstitüsü, Beden Eğitimi ve Spor Anabilim Dalı, (Basılmamış Doktora Tezi) . Eskişehir.

Çelik, V. O. (2016). Sporda Yönetsel Uygulamalar ve Liderik. R. Ekmekçi içinde, Sporda Yönetim ve Organizasyon (s. 61-88). İstanbul: Ergün Yayınevi.

Doğan, S. (2018). Çağdaş Liderlik Yaklaşımları Vizyoner Liderlik, Dönüşümcü Liderlik, İşlemci Liderlik. N. Güçlü içinde, Eğitim Yönetiminde Liderlik: Teori Araştırma ve Uygulama (s. 97-141). Ankara: Pegem Akademi. 
Donuk, B. (2006). Türkiye Profesyonel Futbol Ligleri Antrenörlerinin Liderlik Tarzlarının İncelenmesi ve Bir Moderl Yaklaşımı. Marmara Üniversitesi, Sağlık Bilimleri Enstitüsü, Beden Ĕ̆itimi ve Spor Anabilim Dalı, (Basılmamış Doktora Tezi) . İstanbul.

Ekşili, N. (2019). Pozitif Liderlik Modeli. Mehmet Akif Ersoy Üniversitesi, Sosyal Bilimler Enstitüsü, Işletme Ana Bilim Dalı, Basılmamış Doktora Tezi . Burdur.

Eren, E. (2014). Örgütsel Davranış ve Yönetim Psikolojisi. İstanbul: Beta Yayıncılık.

Gökçe, Z. (2005). Spor yönetiminin farklı boyutlarında yer alan spor yöneticilerinin liderlik tiplerinin araştırılması (Ege bölgesi örneği). Celal Bayar Üniversitesi, Sağllk Bilimleri Enstitüsü, Beden Ĕ̆itimi Öğretmenliği Anabilim Dalı, Sporda Psiko-Sosyal Alanlar Bilim Dalı, (Basılmamış Yüksek Lisans Tezi) . Manisa.

Gündoğdu, F., ve Sunay, H. (2018). Türk Spor Teşkilatındaki Spor Yöneticilerinin Liderlik Stilleri. SPORMETRE , 16 (2), 178-195.

Gündoğdu, F. (2014). Spor Yöneticilerinin Liderlik Stilleri ile Sporun Yaygınlştırılması Arasındaki İlişki. Ankara Üniversitesi, Sağlık Bilimleri Enstitüsü, Beden Eğitimi e Spor Anabilim Dalı, (Basılmamış Doktora Tezi) . Ankara.

Güney, S. (2001). Yönetim ve Organizasyon. Ankara: Nobel Yayın Dağıtım.

House, R., \& Mitchell, T. R. (1975). Patch-Goal Theory of Leadership. Faculty of Management Studies Univercity of Toronto , 2, 1-18.

Jiang, J. (2014). The Study of the Relationship between Leadership Style and Project Success. American Journal of Trade and Policy , 1 (1), 51-55.

Kandemir, D. (2017). Elazı̆̆ ilinde farklı bireysel spor dallarında görev yapan antrenörlerin liderlik tarzlarının incelenmesi. Selçuk Üniversitesi, Sağllk Bilimleri Enstitüsü, Beden Ĕ̆itimi ve Spor Anabilim Dalı (Basılmamış Yüksek Lisans Tezi) . Konya.

Karakaplan Özer, E. (2019). Etkili Liderlik ile Duygusal Bağlılık İlişkisinde İşveren Markası Alg1sının Aracılık Etkisi ve Araştırma. İnönü Üniversitesi, Sosyal Bilimler Enstitüsü, (Basılmamış Doktora Tezi). Malatya.

Kılınç, E. (2019). Stratejik ve Dönüşümcü Liderlik ile İşgören Performansı İlişkisi: Sağlık Seköründe Bir Araştırma. İnönü Üniversitesi, Sosyal Bilimler Enstitüsü, Yönetim ve Organizasyon Anabilim Dalı, Basılmamış Doktora Tezi . Malatya.

Kılınç, Z. (2013). Kadın Spor Ymneticilwerinin Labirentteki Yolculuğu: Liderlik Becerileri, Algılanan Engeller ve Toplumsal Cinsiyet Rolleri. Abanr İzet BaysalÜniversitesi, Sosyal Bilimler Enstitüsü, Spor Yöneticiliği Ana Bilimdalı, (Basılmamış Doktora tezi) . Bolu.

Kocamaz Adaş, S., Dursun, M., Arı, Ç., ve Ulun, C. (2019). Spor Örgütlerinde Çlaışan Bireylerin Lider Kavramına İlişkin Metaforik Algıları. O. Kızar içinde, Spor Bilimler Alanında Araştırma Makaleleri - 1 (s. 199-214). Ankara: Gece Akademi.

Koçel, T. (2005). Işsletme Yöneticiliği . İstanbul: Arıkan Basım Yayım Dağıtım Ltd. Şti.

Köseoğlu, D. (2019). Liderlik Tiplerinin İnsan Kaynakları Yönetimini Algılamaya Etkisi: Yerel Yönetimlerde İnsan Kaynakları Yöneticileri Üzerine Bir Araştırma. Sakarya 
Üniversitesi, Sasyal Bilimler Enstitüsü, Çalışma Ekonomisi ve Endüstri İlişkileri Anabilim Dalı Sakarya.

Kurnaz, S. (2019). Liderlik Tarzı Örgütsel Sessizlik İlişkisinde Örgütsel Politikanın Düzenleyici Rolü: Kamu Kurumlarında Bir Araştırma. İnönü Üniversitesi, Sosyal Bilimler Enstitüsü, Siyaset Bilimi Ve Kamu Yönetimi Anabilim Dall, Yönetim Bilimleri Bilim Dalı (Basılmamış Doktora Tezi), . Malatya.

Küçüközkan, Y. (2015). Liderlik ve Motivasyon Teorileri: Kuramsal Bir Çerçeve. Uluslararası Akademik Yönetim Bilimleri Dergisi , 1 (2), 86-115.

Mızrak, O., Katkat, D., ve Yenel, F. İ. (2004). Spor Federasyonlarında Görev Yapan Genel Sekreterlerin Liderlik Analizi. Atatürk Üniversitesi Beden Eğıtimi ve Spor Bilimleri Dergisi, 26-34.

Okçu, V. (2011). Dönüşümcü Liderlik ve İşlemci Liderlik. İ. Bakan içinde, Yönetimde Çağdaş ve Güncel Konular (s. 425-456). Ankara: Gazi Kitapevi.

Özdinç, Ö. (2014). Türkiye'deki Spor Örgüt Yöneticileri Üzerinde Duygusal Zeka ve Liderlik Davranışları İlişkisinin İncelenmesi. Çukur ova Üniversitsi, Sağlık Bilimleri Enstitüsü, Beden Eğitimi ve Spor Ana Bilimdalı, (Basılmamış Doktora Tezi) . Adana.

Paksoy, M. H. (2010). Küreselleşme ve Liderlik. C. Serinkan içinde, Liderlik ve Motivasyon Geleneksel ve Güncel Yaklaşımlar (s. 1-32). Ankara: Nobel Yayın Dağıtım.

Serinkan, C. (2010). Liderlik ve Motivasyon. C. Serinkan içinde, Liderlik ve Motivasyon Geleneksel ve Güncel Yaklaşımlar (s. 149-178). Ankara: Nobel Yayın Dağıtım.

Şirin, E. F. (2008). Beden Eğitimi ve Spor Yüksekokulu Yöneticilerinin Liderlik Stilleri ve Çatışma Yönetimi Stratejlerinin İncelenmesi. Gazi Üniversitesi, Ĕğtim Bilimleri Enstitüsü, Beden eğitimi ve Spor öğretmenliği Anabilim Dalı, (Basılmamış Doktora Tezi) . Ankara.

Temel, V. (2010). Konya İline Ait Bireysel ve Takım Sporu ANntrenörlğü Yapan Bireylerin Liderlik Tarzlarının Karşılaştırılması. Karamanoğlu Mehmetbey Üniversitesi, Sosyal Bilimler Enstitüsü, Beden Egitimi Ve Spor Ögretmenligi Anabilim Dalı, Beden Egitimi Ve Spor Ögretmenligi Bilim Dalı, (Basılmamış Yüksek Lisans Tezi) . Karaman.

Terlemez, M. (2019). Sporda Liderlik Tipleri, Yaklaşımları ve Fonksiyonları. Oğuzhan Sosyal Bilimler Dergisi , 138-151.

Tunçer, P. (2012). Yönetim ve Organizasyon. İstanbul: Beta Yayıncılık.

Wanasika, I. (2006). İn Search of Global Leadership. Journal of International Bussiness and Cultural Studies (1), 1-17.

Yeşil, A. (2016). Liderlik ve Motivasyon Teorilerine Yönelik Kavramsal Bir İnceleme. Uluslararası Akademik Yönetim Bilimleri Dergisi , 2 (3), 158-180.

Yeşil, S. (2013). Küresel ve Değişen Çevre Dinamikleri Işı̆̆ında Yeni Yönetim Yaklaşımlarından Seçme Konular. Ankara: Şeçkin Yayıncılık.

Yetim, A. A. (1996). Spor Yönetiminde Liderlik. Beden Ĕ̆itimi Spor Bilimleri Dergidi I (3), 8594. 